\title{
THE PROPOSED FOOD AND DRUGS ACT: A LEGAL CRITIQUE
}

\author{
Mitchell SALEM Fisher*
}

The proposal for a new federal Food and Drugs Act $^{1}$ is but another phase of increased interest on the part of the Roosevelt Administration in the problems of the purchasing public, an interest already evinced by the National Securities Act.

The task of the present article is not to venture a study in ethics nor in the factual background of food and drug legislation nor even to wage polemics on behalf of the proposed bill. The object of this study is more mundane: to view the bill in its relation to the present federal Food and Drugs $\mathrm{Act}^{2}$ and to speculate with legal

- Mitchell Salem Fisher, B.A., 1923, New York University; M.A., 1927, Columbia University; M.H.L., 1927, Jewish Institute of Religion; LL.B., 1933, Columbia University. Editor: Columbia Law Review, 1931-r933. James Kent Honorary Fellow, Columbia University School of Law, 1932-r933. Member of the New York Bar. Associated with Guggenheimer and Untermyer, Attys., of New York City. Author of Philosophy and Better Understanding in CHRISTIAN AND JEW (ed. Landman, 1928) and of articles in various philosophical periodicals.

The writer wishes to acknowledge his great indebtedness to Miss Esther Oshiver, recent graduate of the University of Pennsylvania Law School, for her extensive and helpful research into the field of food and drug control by the several states and the question of civil liability for violation thereof. Only his modest disregard of his extensive and valuable critical labors on the manuscript has prevented the name of Professor Milton Handler, counsel to the National Labor Board, being added as a co-author. The writer, however, takes sole responsibility for the positions assumed with regard to the bill. Acknowledgement is made to the Columbia.Law Review for permission to use in part the writer's legislation note, The Consumers' Protection under the Federal Pure Food and Drugs Act (1932), 32 Columbia Law Revicw, 720.

${ }^{1}$ S. 1944, 73rd Cong. Ist Sess. (r933). The bill was introduced by Senator Copeland and referred to the Committee on Commerce. H. R. 6IIo, 73rd Cong. Ist Sess. (r933) introduced by Congressman Sirovitch parallels the Copeland bill with the exception of Section 3 which requires that all drug containers shipped in interstate commerce must have a label bearing a registered trade mark and attempts in other ways to use the trade mark method for securing disclosure of ingredients.

Throughout this article, wherever reference is made to the "bill," the Senate bill is intended. "Act" (unless otherwise qualified) will mean the present law. For discussion of S. 1944, sce Tugwcll, The Copeland Bill and the Food Industries, Grocery TrAde News, Oct. 24, 1933; Campbell, A New Food and Drugs Act (1933) I7 U. S. DePt. AGR. Food Rev., No. 7; Handler, Revision of Federal Food and Drugs Law, Ort, Paint and Drug Rep., June 26, I933, at I7; Analyzing the New Drug Act, Dnug and Cosmetic INDUSTRY, Aug. 1933.

34 Stat. 768 (I906), amended by 37 Stat. 4 I6 (IgI2), 37 Stat. 732 (Ig13), 4x Stat. 27x (Igr9), 42 Stat. I500 (I923), 46 Stat. IoIg (I930), 2 I U. S. C. A. \$\$I-I5, \$ro(5) (Supp. I932). The Act and its amendments, the Rules and Regulations (Ninth Revision) issued thereunder, the Regulatory Announcements, Definitions and Standards, the more important Food Inspection decisions, and texts of related federal and state statutes are collected in I DunN, Food and Drug Laws (1927) (Supp. 1929). The Rules and Regulations will be noted as "Reg."; Regulatory Announcements, as "Reg. Ann."; Food Inspection Decisions, as "F. I. D."; and Notices of Judgment, as "N. J." 
technology concerning its scope, limitations, validity and effect. Such an analysis is of particular importance in view of the fact that the present form of federal legislation on the subject which was enacted in 1906 in response to the demand for wider federal action ${ }^{3}$ rapidly became the prototype for state enactments ${ }^{4}$ and the probability that the present bill, if passed, will similarly serve as a model for future food and drug regulation in the various states.

\section{Basis of Violation Under the Present Act}

Contrary to popular conception, the Act as now phrased does not directly penalize misbranding and adulteration. ${ }^{5}$ It attempts regulation by indirection, $i . e$, it closes the stream of foreign and interstate commerce to both misbranded and adulterated articles of medicine and food. Until a shipment occurs, no violation is possible, despite the fact that articles designed for interstate commerce may have been adulterated or misbranded. For with the exception of the provisions governing the District of Columbia and the territories ${ }^{6}$ the Act controls only transportation, forbidding the shipment or delivery for shipment in interstate commerce, or the receipt and delivery (or offer of delivery) in original unbroken packages after an interstate jour-

\footnotetext{
'For a history of early legislation on foods and drugs in America and the agitation leading up to the law, sec Weber, The Food, Drug, and Insecticide Administration, ITs History, Activities, and ORGanization (1928); Dunn, History of United States Food Laws (1926) 21 AM. Food J. 564; Conover, National, State, and Local Coöperation in Food and Drug Control (1928) 22 AM. Pol. Sc. REv. 910; The Laws That Govern Drugs, Ax. Druggrst, Oct. 1933, at 88. See also Maxey, Federal Quarantine Laws (1909) 43 AM. L. REv. 382.

"See Conover, supra note 3, at 9r3; Holt, Uniform Legislation (I927) 22 AM. Food J. 3; Legis. (I93I) 31 Cor. L. Rev. 872,873 n. 8 . The existence of the Act invalidated a state law in only the one instance where the state statute was interpreted as necessarily calling for the removal of the federal label. McDermott v. Wisconsin, 228 U. S. II5, 33 Sup. Ct. 43I (Igr3). See Note (1913) 27 Harv. L. REv. 75. Unless thus directly interfering with the enforcement, Congress has not so "occupied" the field that the state may not prescribe additional standards of purity for the privilege of retail sale [Savage v. Jones, 225 U. S. sor, 32 Sup. Ct. 715 (I912); Hebe Co. v. Shaw, 248 U. S. 297, 39 Sup. Ct. 125 (I919); Armour \& Co. v. North Dakota, 240 U. S. 510,36 Sup. Ct. 440 (rgr6)] even though the sale be made in the original packages. Standard Stock Food Co. v. Wright, 225 U. S. 540,32 Sup. Ct. 784 (1912); Corn Products Refining Co. v. Eddy, 249 U. S. 427, 39 Sup. Ct. 325 (1919). The mere fact that a state statute follows mutatis mutandis the federal Act is not determinative. Corn Products Refining Co. v. Eddy, supra, at 438,39 Sup. Ct. at 330. Nor does the federal Act interfere with supplementary legislation by insular possessions. Gonzalez v. People of Porto Rico, 5 I F. (2d) 6I (C. C. A. Ist, I93I). Compliance with federal standards does not secure the right to interstate transportation free from "reasonable" regulation by the state. Sligh v. Kirkwood, 237 U. S. 52, 35 Sup. Ct. 50I (r9I5); Weigle v. Curtice Bros. Co., 248 U. S. 285, 39 Sup. Ct. 124 (r919); see Note (I92I) I9 Mrch. L. Rev. 739. Municipal ordinances do not interferc. See E. Fougera \& Co. v. City of New York, 224 N. Y. 269, 280, r20 N. E. 642, 644 (1918). Articles shipped in violation of the Act may become subject to state laws otherwise inapplicable. State v. Intoxicating Liquors, $104 \mathrm{Me} .502,7$ I Atl. 758 (1908). When an article of food is taken from the interstate package upon receipt and placed in other packages sold within the state, the federal Act does not apply. REG. ANs. 96. On the whole subject of the Act in relation to the "original package" doctrine, see F. I. D. No. 86 (rgo8).

Weeks v. U. S., 245 U. S. 6r8, 38 Sup. Ct. 219 (I9I8).

- Section $I$ of the Act prohibits the manufacture of misbranded or adulterated food and drugs in the District of Columbia or the territories. Section 2 forbids their being sold or offered for sale in the District of Columbia or the territories. These sections do not apply to the insular possessions. Gonzalez v. People of Porto Rico, supra, note 4. But transportation into and from the insular possessions is controlled by the Act, 5 ro.
} 
ney, of misbranded or adulterated foods and drugs. ${ }^{7}$ The Supreme Court in the Hipolite $E g g$ case $^{8}$ decided that this shipment need not be for purposes of ultimate sale and that the law had application though the shipment consist of raw material for use in the preparation of a more complex food product. The substandard food or drug is not permitted to cross the state line even when the shipment is made for the express purpose of removing impurities in the receiving station ${ }^{0}$ or for testing for export at such station. ${ }^{10}$ Similarly, rotted foodstuffs may not be sent from state to state for tanning or other non-food purposes, unless so denatured as to make their consumption by the public impossible. ${ }^{11}$ The excuse that a shipment of drugs constituted but part of medical "services" which were being rendered has similarly failed.12 The question, however, has remained open whether an individual practitioner violates the law if he sends his patient a drug package with a non-complying label. ${ }^{13}$

\section{Basis of Violation UNDER the BiLl}

The states, untrammelled by the constitutional limitations of the "commerce" clause, have made the tampering with the food or drug the offense, ${ }^{14}$ and have

${ }^{7}$ See Acr, \$2. (Manufacture and sale of adulterated or misbranded products are prohibited in the District of Columbia and the territories by $\delta$ r.) The defendant need not be either a manufacturer, owner, or dealer in the commodity. U. S. v. Buffalo Cold Storage Co., 179 Fed. 865 (W. D. N. Y. 1910). The restriction as to "original unbroken packages" applies only to the receiver of the adulterated or misbranded goods and not to the shipper. See U. S. v. Krumm, 269 Fed. 848, 849 (E. D. Pa. 1921). Under Section 2 the shipment is a violation both in the judicial district from which it is made and to which it is sent. U. S. v. Alaska Consolidated Canneries, 2 F. (2d) 6 44 (W. D. Wash. 1924). But since the crime is actual shipment, merely contracting or ordering for shipment is not a basis for prosecution. See U. S. v. Hopkins \& Co., 199 Fed. 649,652 (E. D. N. Y. I912). Nor selling to one who may intend to use a product in interstate commerce. Lewiston Milling Co. v. Cardiff, 266 Fed. 753 (C. C. A. gth, 1920), cert. denied, 254 U. S. 646, 4 I Sup. Ct. 15 (1920). But $c f$. U. S. v. Heinle Specialty Co., r75 Fed. 299 (E. D. Pa. rgro). A sale and delivery which necessarily involves interstate transportation may violate the Act though the delivery be to an agent of the foreign receiver within the state. $C f$. U. S. v. Tucker, $x 88$ Fed. $74 \mathrm{I}$ (S. D. Ohio I9II).

${ }_{8220}$ U. S. 45, 3I Sup. Ct. 364 (I9IX). Accord: U. S. v. Two Barrels, Dessicated Eggs, 185 Fed. 302 (D. Minn. IgII); U. S. v. 426 Bags, Hog Feed, 276 Fed. 34 (W. D. Mich. 192x).

'Union Dairy Co. v. U. S., 250 Fed. 231 (C. C. A. 7th, r9I8); U. S. v. Nine Barrels, Butter, 24I Fed. 499 (S. D. N. Y. 1917); see U. S. v. 94 Dozen Bottles, Capon Springs Water, 48 F. (2d) 378, 381 (E. D. Pa. 1930), $a f f^{\prime} d, 5$ I F. (2d) 9 I3 (C. C. A. 3d, I93I). Prior to the Hipolite case a manufacturer was allowed to ship to his own agents goods to be properly labeled when finally manufactured. U. S. v. 65 Casks, Liquid Extracts, 170 Fed. 449 (N. D. W. Va. 1909). The Hipolite case involved a shipment to a stranger, but the later decisions broadened the rule. Seo Philadelphia Pickling Co. v. U. S., 202 Fed. 150, 154 (C. C. A. 3d, 1913). On the importation of food-stuffs for non-food purposes, see Reg. 30 . But proper labeling on the part of the receiver prior to seizure by the federal authorities has been held to give the goods immunity. U. S. v. Five Boxes, Asafoetida, I8I Fed. 56r (E. D. Pa. Igro).

${ }^{10}$ Philadelphia Pickling Co. v. U. S., supra note 9. Under Section 2 articles are not misbranded or adulterated when intended for export and prepared or packed according to the specifications of the forcign purchaser and in addition do not contain substances in conflict with the forcign law. But note the discussion of this section, infra p. 109. It is significant that the bill omits this exemption.

${ }^{21}$ U. S. v. I3 Crates, Frozen Eggs, 208 Fed. 950 (S. D. N. Y. x913), aff'd, 215 Fed. 584 (C. C. A. 2d, 1914); see REG. ANN. 322 (shipment for manufacturing purposes).

${ }_{12}$ Dr. J. L. Stephens Co. v. U. S., 203 Fed. 8I7 (C. C. A. 6th, 19r3).

12Id. at 819, 824; F. I. D. No. 57 (1907).

${ }^{14}$ For control of tampering, see e.g., ARIz. Rev. Code (Struckmeyer, I928) \$2702. N. M. STAT. ANN. (1929) \$\$53-I02-53-104; N. Y. Cons. LAws (Cahill, 193I) c. I, \$198. Cf. also Porto Rico PEN. Code, $\$ 336$ (repealed), see Pen. Code 5474; Rev. Stat. \& Codes (rgir) 55928. 
analogously supported their control by placing restraints upon retail sale. ${ }^{15}$ Likewise in England ${ }^{18}$ and Canada ${ }^{17}$ legislative attention has been increasingly devoted to checking activities of the selling public other than mere transportation.

To a limited extent only does the bill move in this direction. So far as the adulteration and misbranding of foods, drugs, or even cosmetics (which are now for the first time to be brought within the scope of the law) are concerned, the bill merely repeats the prohibition of their introduction ${ }^{18}$ or receipt and delivery ${ }^{18}$ in interstate commerce. The bill's novelty lies in the manner of its attempt to control advertising: it scores not the movement of falsely advertised food, drug, or cosmetic packages in interstate commerce but (I) the dissemination of false advertisement by radio broadcast, United States mails, or in interstate commerce generally for the purpose of inducing, directly or indirectly, the purchase of these articles ${ }^{20}$ and (2) the dissemination of false advertisement by any means for the purpose of inducing, directly or indirectly, the sale of food, drugs, or cosmetics in interstate commerce. ${ }^{21}$ This failure to forbid the actual inundation of interstate commerce by falsely advertised foods, drugs, and cosmetics narrows the scope of the control and the failure to apply the seizure provisions of the law to such articles may rob the bill's false advertising anathema of most important sanctions. ${ }^{22}$ Their application would, of course, present the difficult problem of determining how long and over what territory a false advertisement would justify seizure. The other changes which the bill makes in the strictly technical basis of the federal regulation are minor. ${ }^{23}$

${ }^{25}$ The regulation of sale is common. See I DunN, op. cit. supra note 2, passim. See, e.g., Ariz. REv. Code (Struckmeyer, 1928) \$27II. For a review of state regulation of the sale of drugs in pharmacies, see Note (1929) 17 Calip. L. Rev. 665.

${ }^{10}$ In England the basis of the offense consists in (I) mixing, staining, powdering, etc., food articles (with intent to sell) so as to render them injurious to health or doing similar acts to drugs so as injuriously to affect quality or potency; (2) selling an article to prejudice of purchaser which is not of nature, substance, or quality demanded by the purchaser; (3) abstracting part of the article so as intentionally to make its effect injurious; (4) wilfully applying certificate or warranty for another or wilfully giving a false label. I8 \& I9 GEO. V, c. $3 \mathrm{I}, \$ 5 \mathrm{r}, 2,5,30$ (I928).

${ }^{17}$ It is an offense to attach misleading labels or to neglect or refuse to label in accord with the Canadian Act. Can. Rev. Stat, (1927) c. 76 \$32. For a summary of recent developments in the English legislation, see (1932) 96 Just. P. 88.

"BILI, $5 \mathrm{I7}$ (a) (I). The use of the term "introduction" does not add anything to the existing law. $C f$. the use of the same term in the Act, $\$ 2$. "Interstate commerce" under the bill is a term of art and includes foreign commerce. $C f$. BiLL, $\$ 2$ (c) (I). Interstate commerce is also defined as "commerce and manufacture within the District of Columbia or the Canal Zone or within any territory not organized with a legislative body." Id. \$2 (c) (2). This part of the definition is anomalous. Commerce between the District of Columbia and other states is not expressly included in Section 2 (e) ( $x$ ). and the apparent result is that to violate the new Act in the District of Columbia and the insular possessions one must be shown to have "introduced" the food or drug article into both commerce and manufacture.

10 BiLI, 517 (a) (2).

${ }^{20} \mathrm{BILL}, \$ 17$ (a) (3). The purchase need not be made through a channel of interstate commerce.

"BILI, 517 (a) (4). Questions may well arise as to whether the "sale" covered by this section means one which must necessarily result in or induce a transportation of the article across state boundaries. That such must be its meaning is clear when one considers that all "sales" are legally localized within particular states.

"See infra p. III. To a limited extent, the bill may prohibit such shipment where the extra-package publicity is made in media technically elassed under "labeling." See infra p. 86.

"Section 17 (a) (5) forbids the introduction into interstate commerce of foods, drugs, and cosmetics if 


\section{MIsBRANDING UNDER THE ACT}

The differences which the proposed legislation introduces in the control of misbranding can be revealed only by a close comparison of Sections 6,7 and 8 of the bill with Section 8 of the Act and the decisions and regulations interpreting and enforcing the latter. For in both the bill and the Act "misbranded" is largely a word of art. An analysis of Section 8 of the Act shows three discrete types of "misbranding":

(I) Where the label is affirmatively false or misleading; ${ }^{24}$

(2) Where the label fails to state the quantity or proportion of ten enumerated drugs, their derivatives, or compounds, ${ }^{25}$ or in the case of packaged goods, omits conspicuous marks of weight, measure or numerical count; ${ }^{26}$

(3) Where the product is an imitation of, or is offered for sale under, the name of another article. ${ }^{27}$

The "label" includes any legend, design, or pictorial device on the package itself, pasters or tags, pamphlets, circulars, etc., affixed to the outside of the package, ${ }^{28}$ and pamphlets and circulars enclosed within the package in the case of therapeutic misrepresentations under the Sherley Amendment. ${ }^{29}$ Perhaps also misstatements as to

the manufacturer, processor, or packer does not hold a valid permit when required. See infra p. Ios Section 17 (a) (6) penalizes a refusal to permit access to or copying of certain records of interstate ship. ment, by carriers subject to the Interstate Commerce Act. Cf. BILL, \$I4. For a similar duty upon carriers under a state food and drug law, cf. ILI. Rev. Stat. (Cahill, I929) c. 56b, \$3. Many states have provisions which make it a crime to hinder, obstruct, or interfere with food and drug inspection. Sec, e.g. 2 Ind. Stat. Ann. (Burns, r926) \$8230; Izl. Rev. Stat. (Cahill, r929) c. 56b, \$3. Sce also Can. Rzv. SraT. (I927) c. $76, \$ 27$. For a provision specifically exempting common carriers who innocently receive adulterated or misbranded articles of food in the ordinary course of business, see Iowa CoDE (I93I) \$3049.

2s The statement, design, or device must be misleading or false regarding the article contained in the package to which the label is affixed, the ingredients or substances contained therein, or regarding territorial source. Section 8 is so worded as to exclude statements which are misleading as to other articles in competition with that in the labeled package.

${ }^{25}$ The drugs which must be mentioned are alcohol, morphine, opium, cocaine, heroin, alpha or beta eucaine, chloroform, cannabis indica, chloral hydrate, or acetanilid, or any derivative or preparation of such substances. AcT, $\$ 8$ (Drugs, 2). Food products must be labeled and indicate the presence of these substances with the exception of alcohol. Id. (Food, 2). The presence of alcohol must be indicated even in a preparation used only for inhalation. The Congressional intent in forcing the disclosure was not only to reduce the consumption of liquor and prevent the innocent formation of the habit of liquor drinking but also to inform the consumer of the presence of the enumerated drugs. U. S. v. I I Cartons, Drug, ctc., 59 F. (2d) 446 (D. Md. 1932). Not only must the derivative be indicated on the label but also the name of the specified drug of which it is a derivative. U. S. v. Antikamnia Chemical Co., 23I U. S. 654, 34 Sup. Ct. 222 (1913). Cf. also Reg. 24 (Substances required to be stated on label). As to when the term "Poison" must appear on the label, see the Caustic Poison Act, 44 STaT. 1406 (1927), I5 U. S. C. A. $\$ \$ 402,403$ (Supp. 1933).

${ }^{20}$ Cf. Reg. 26. This provision of the law was added by the Gould Amendment, 37 STAT. 732 (1913), $2 I$ U. S. C. A. \$ro (3), in turn amended by the Kenyon Amendment defining its application to wrapped meats. 4 I STaT. 27 I (I9I9), 2 I U. S. C. A. \$Io. The Bill deals with the wrapped meat problem by including such articles in the term "in package form." Cf. BiLL, \$2 (k). The statute expressly permits "reasonable variations" as to weights and counts. This permission does not render the paragraph unconstitutional as setting up too "indefinite" a standard in a criminal statute. U. S. v. Shreveport Grain \& Elevator Co., 287 U. S. 77, 53 Sup. Ct. 42 (I932). Cf. U. S. v. Rigney \& Co., 220 Fed. 734 (E. D. N. Y. x915).

${ }^{27}$ For a violation of (3) no deceptive label is necessary. The offer may be made by the oral representations of a salesman. Weeks v. U. S., supra note 5 .

${ }^{28}$ Reg. 14 .

${ }^{2} 37$ STAr. 4 I6 (1912), 21 U. S. C. A. \$ro (Drugs, 3). The Congressional power validly extends to 
non-therapeutic effects when made in the circulars are prohibited in the rare case in which the label itself refers to such representations and incorporates them by the reference. ${ }^{30}$ The federal label clearly includes not only that on the outer carton, but also that physically attached to the retail package. ${ }^{81}$

Two statutory exceptions are made: (a) mixtures or compounds known as articles of food and sold under their own distinctive names and which neither contain added poisonous or deleterious ingredients, nor violate (3) above are not to be deemed misbranded where the distinctive name is accompanied with a statement of the place of manufacture; 32 (b) compounds, imitations or blends are not misbranded if plainly tagged or labeled "compound," "imitation," or "blend" respectively. The "blend" must be a mixture of like substances. ${ }^{33}$

The Act's protection is not narrow. Thus, cornstarch may be botanically a fruit but its presence cannot make an article "fruit"-flavored. ${ }^{34}$ The test of the label's truth is not chemical, botanical, or scientific accuracy ${ }^{35}$ but rather the generally understood signification of the label as a concatenated whole ${ }^{38}$ to persons of ordinary intelligence, familiar with the product, and conversant with the English language.37 Similarly, the fact that the term used in the label correctly characterizes the product to people aware of a special trade nomenclature or custom does not matter ${ }^{38}$ unless such nomenclature or custom be so widespread as to negate the possibility of deception. ${ }^{38}$ But an otherwise truthfully labeled product must, however, meet the requirements of a fully developed trade connotation. ${ }^{40}$

The label may not misstate the nature or the identity of the article, ${ }^{41}$ or imply that circulars contained within the package. Seven Cases, Eckman's Alterative v. U. S., 239 U. S. 510, 36 Sup. Ct. Igo (I916). Contra: (prior to the amendment) U. S. v. Am. Druggists' Syndicate, I 86 Fed. 387 (C. C. E. D. N. Y. I9II). The Sherley Amendment has been held to include under "label" booklets enclosed within the carton only where false and fraudulent representations are concerned. U. S. v. I7 Bottles, etc., 55 F. (2d) 264 (D. Md. r932).

${ }^{30}$ Reg. 14 .

s1 MeDermott v. Wisconsin, stipre note 4 at $\mathrm{r} 3 \mathrm{I}, 33$ Sup. Ct. at 434 . But an invoice is not a label under the Act. Hall-Baker Grain Co. v. U. S., r98 Fed. 6I 4 (C. C. A. 8 th, I912).

22 Cf. Reg. 18.

${ }^{3}$ Cf. Reg. Ig.

"U. S. v. 150 Cases, Fruit Puddine, 211 Fed. 360 (D. Mass. I914).

${ }^{23}$ U. S. v. Scanlon, I80 Fed. 485 (N. D. Ohio, I908); U. S. v. 75 Boxes, Alleged Pepper, I 98 Fed. 934 (D. N. J. I9I2). In considering whether a food product is misbranded, the courts will turn to the designations given in dictionaries, trade journals, the trade, market reports, newspapers and official publications regarding food. See U. S. v. One Car Load, Corno Horse \& Mule Feed, I88 Fed. 453, 463 (M. D. Ala. IgII).

${ }^{3}$ See Newton Tea \& Spice Co. v. U. S. 288 Fed. 475,479 (C. C. A. 6th, 1923).

${ }^{27}$ See U. S. v. 75 Boxes, Alleged Pepper, supra note 35, at 935; U. S. v. One Car Load, Corno Horse \& Mule Feed, supra note 35 , at 462 .

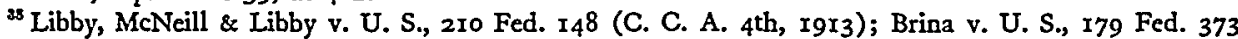
(C. C. A. 2d, I9ro). But the federal Act does not interfere with the contracts of parties for shipment of products described under trade names. Walker v. Gateway Milling Co., 12r Va. 217, 92 S. E. 826 (r917).

${ }^{30}$ Von Bremen v. U. S., r92 Fed. 904 (C. C. A. 2d, r912); see Brina v. U. S., supra note 38 ; cf. U. S. v. 30 Cases, Grenadine Syrup, I99 Fed. 932 (D. Mass. 1912). Cf. (I933) 3I Mrcr. L. Rev. 804, 816. It has been suggested that under the Act, no commercial practice could legally establish a novel system of liquid and weight measures. U. S. v. Rigney \& Co., supra note 26 , at 736 .

${ }^{0}$ U. S. v. 75 Boxes, Alleged Pepper, supra note 35.

${ }^{4}$ U. S. v. 95 Barrels, Vinegar, 265 U. S. 438 , 44 Sup. Ct. 529 (1924); U. S. v. Five Cases, Champagne, 205 Fed. 817 (N. D. N. Y. I913) (even though the name of the article represented does not appear on 
it contains ingredients actually absent. ${ }^{42}$ Michigan apples cannot be presented as coming from Arkansas trees; ${ }^{43}$ the Act protects geographical terms ${ }^{44}$ unless the terms have become so generic as to indicate types, classes, or styles rather than places of origin or manufacture. ${ }^{45}$ The product must also satisfy its package's representations as to strength, quality, grade or purity. ${ }^{46}$

Nor has the immunity of the statutory exceptions been altogether easy to gain, nor when gained, has such immunity proved absolute. The courts have held that to give a proprietary food product a distinctive name which suggests ingredients which are in fact absent is to employ not "its own distinctive name," distinguishing it from other compounds, but rather the name of a different compound possessing those ingredients and hence is deceptive. ${ }^{47}$ And merely utilizing the words "compound" or "blend" does not exempt wares from other statutory inhibitions, ${ }^{48}$ especially where the word "compound" is used as an adjective suggestive of "added strength" rather than indicative of an internal combination of substances. ${ }^{40}$

The misbranding of drugs forms a separate topic. In IgrI the Supreme Court in United States v. Johnson ${ }^{50}$ held the term "misbranded" to apply only to false state-

the label); Washburn \& Co. v. U. S., 224 Fed. 395 (C. C. A. Ist, I915); Libby, McNeill \& Libby, supra note 38. Cf. Johnson, The Case of "Courts vs. Bureaucrats" (Nov. I93I) Standard Remedies, 2, 4.

Newton Tea \& Spice Co. v. U. S., supra note 36 .

${ }^{4}$ U. S. v. 100 Cases, Tepee Apples, x79 Fed. 985 (W. D. Mo. r908).

"U. S. v. 267 Boxes, Maçaroni, 225 Fed. 79 (W. D. Pa. 1915) ("mfg. in U. S." printed in small letters where all wording in Italian and name of Italian city used); Schraubstadter v. U. S., 199 Fed. 568 (C. C. A. 9 th, rgr2) (court considers "dress" of the package). The problem of deception when a local American city has the same name as a foreign country is often a close onc. Cf. U. S. v. Finlayson, N. J. No. 2914 (S. D. N. Y. Igr3); U. S. v. Schurman, I77 Fed. 58I (W. D. Mich. 1910).

${ }^{4}$ U. S. v. Thomson \& Taylor Spice Co., I98 Fed. 565 (N. D. Ill. 1912), with which cf. F. I. D. No. $9 I$ (1908); U. S. v. 36 Bottles, London Dry Gin, 205 Fed. III (E. D. Pa. Igr3), rev'd on other grounds, 210 Fed. 27I (C. C. A. 3d, I914). In I9ro, F. I. D. No. II5 restricted the term "Rocky Ford" melon to melons of a particular locality; F. I. D. No. 166 reversed that decision because by Igr 6 the term had become sufficiently generic. On foreign names, see Reg. I7. For the problem raised by the use of the term "whiskey," see F. I. D. No. I27 (I9I0); TAFT, What Is the Meaning of the TERM "Whiskex" (Govt. Printing Office, Ig09).

${ }^{20}$ Wood Mfg. Co. v. U. S., 286 Fed. 84 (C. C. A. 7th, I923); U. S. v. 200 Cases, Canned Salmon, 289 Fed. I57 (S. D. Tex. I923).

${ }^{\prime}$ U. S. v. Coca Cola Co., 241 U. S. 265,36 Sup. Ct. 573 (19I6), (19r6) 30 HArv. L. Rev. 193. But the proprietary name gives protection where it has achieved a secondary significance descriptive of a product known to be destitute of ingredients indicated by its primary meaning. See U. S. v. Coca Cola, supra at 288,36 Sup. Ct. at $58 \mathrm{r} ;$ Cf. U. S. v. 150 Cases, Fruit Puddine, supra note 34 . The proviso regarding distinctive names does not apply where the charge of misbranding is directed not against the name but against false statements on the label. Newton Tea \& Spice Co. v. U. S., stupra note 36 . The fact that a proprietary name is a trade-mark may tend to a more favorable consideration. See U. S. v. 23 7/12 Dozen Bottles, etc., 44 F. (2d) 831, 838 (D. Conn. I930).

${ }^{4}$ U. S. v. Schider, 246 U. S. 519, 38 Sup. Ct. 369 (I918) ("Compound Ess Grape" insufficient to show product an imitation); Henning \& Co. v. U. S., r93 Fed. 52 (C. C. A. 5th, r9I2) ("Compound Tomato Catsup" misbranded when product had pumpkin); U. S. v. Ten Barrels, Vinegar, r86 Fed. 399 ( E.D. Wis. IgIr) ("Blend of Apple Cider and Distilled Vinegar" misbranded when product not apple cider vinegar and distilled vinegar). Where product is an imitation, the law is mandatory that word "imitation" appear on label. "Artificial" does not suffice. Reg. Ann. 369.

${ }^{6}$ Frank v. U. S., I92 Fed. 864 (C. C. A. 6th, I9II); U. S. v. Weeks, 225 Fed. Ior7 (S. D. N. Y. I9I2).

${ }^{\text {so }} 22 \mathrm{I}$ U. S. 488,3 I Sup. Ct. 627 (191I). Accord: U. S. v. Hygiene Health Food Co., N. J. 1265 (N. D. Cal. rgrI). 
ments as to the identity or quality of foods and drugs and not to declarations of therapeutic or curative effects. The decision was contrary to departmental interpretation and the probable Congressional intent. ${ }^{51}$ To stop the serious gap created by the decision, Congress passed the Sherley Amendment" ${ }^{52}$ which forbids "false and fraudulent" representations as to the therapeutic effects of drugs. For this type of misbranding, therefore, actual intent to deceive is a condition of the statutory offense, an intent, however, which may be inferred from the circumstances. ${ }^{53}$ Bracketing the medical hocus as a quotation from actually received testimonials has been held but an indirect and invalid method of deception. ${ }^{54}$ The law has taken note also of advance in medical knowledge and experience so that a "cure" or "remedy" which will pass judicial muster in one decade may fail in the next. ${ }^{55}$

The consumer therefore has at the present time a degree of protection from misbranding. Consider now the other side of the picture. The law does not apply to advertising matter in media physically detached from the package, ${ }^{56}$ and by a recent decision even the pamphlets enclosed within the package can legally be both false and misleading. ${ }^{57} \mathrm{~A}$ bottle of orange colored sugar water or a simple cereal food may be correctly labeled. The law may be meticulously observed; yet billboards, newspapers, magazines, and radio may endow them with most valuable ingredients and herald the medicinal virtues of such inert products with blatant charlatanry. ${ }^{58}$ Since interstate shipment is the crime, apparently nothing (as far as the federal Act is concerned) prevents a shipper from sending products across the state boundary line

${ }^{21}$ See the argument for the Government in U. S. v. Johnson, supra note 50, at 490.

20 7 Stat. 4 I6 (IgI2); 21 U. S. C. A. \$1o (Drugs, 3).

- $\approx$ Dr. J. H. McLean Medicine Co. v. U. S., 253 Fed. 694 (C. C. A. 8 th, rgr 8); Bradley v. U. S. 264 Fed. 79 (C. C. A. 5th, 1920); Chichester Chemical Co. v. U. S., 49 F. (2d) 516 (App. D. C. 1931); See Seven Cases, Eckman's Alterative v. U. S., suppra note 29, at 517, 36 Sup. Ct. at 193. Since falsity of therapeutic representations is an element of the violation, expert testimony on that fact is admissible. Hall v. U. S., 267 Fed. 795 (C. C. A. 5th, 1920). As fraudulent intent is an element, self-serving letters are admitted, Chichester Chemical Co. v. U. S., supra, and testimonials received by the defendant are admissible to show his good faith regardless of proof of their execution or of the truth of their subject matter. See Dr. J. H. McLean Medicine Co. v. U. S., supra, at 697 . On refund guaranties connected with therapeutic representations, see Reg. Ann. 21.

${ }^{5}$ U. S. v. Fulton Co., 33 F. (2d) 506 (C. C. A. 9th, 1929).

${ }^{25}$ Cf. Aycock v. O'Brien, 28 F. (2d) $8 \times 7$ (C. C. A. gth, I928), with U. S. v. Tuberclecide Co., 252 Fed. 938 (S. D. Cal. 19I6).

io See Alsberg, Ten Years of Food and Drugs Enforcement, REp. SEC. AGr. (1917) 212; Ballyhoo or Truth? (Dept. Agr., Aug. 28, 1933). Showing in the case of Lydia Pinkham Vegetable Compound the shift of therapeutic claims away from the label, see Leech, The Safeguarding of Drugs in Chemistry in Medrcine (ed. Stieghty, 1928) 395, 400. For an illustration of the inability to reach products advertised through non-package media, see CHASE \& SCHLINK, YOUR MONEY's WorTH (1928) 134. Patent medicines are sold to the public primarily by virtue of non-package advertising, CHase \& ScrLINx, op. cit. supra at 123. Similarly the Packers \& Stockyards Act, 42 STAT. I59 (I921), 7 U. S. C. A. \$181, does not reach such advertising matter. The statutory crime of using the mails to defraud, FED. CRIM. CODE \$215, 35 STAT. I130 (rg09), 18 U. S. C. A. $\$ 338$, and the power of the Post Office Department to issue fraud orders, I7 STAT. 322, 323 (1872), 39 U. S. C. A. \$\$259, 732, are restricted to mail circulars.

${ }^{57}$ U. S. v. I7 Bottles, etc., supra note 29.

${ }^{2 s}$ See (1931) 97 AM. MED. Assn. J. 32; Cramp, Truth in Advertising Drug Products (1920) Io AM. J. Pub. Heattr 783. For an illustration, see Electro-yita-Weak Lime Water Plus Hokum (I932) 98 AM. MEd. AssN. J. 337. 
without a label and then affixing thereon one most outrageously deceptive. ${ }^{6 \theta}$ The only exception is the inferred requirement of a label where the article contains one of the ten enumerated drugs. With a few exceptions, labels when present must mention the presence of only these ten drugs and are immune from any other rules as to affirmative disclosure. ${ }^{80}$ Other poisons and all kinds of habit-forming drugs may be in the article without disclosure being required. ${ }^{61}$ Moreover, except as to the ten drugs $^{82}$ the law is silent as to the proportion of ingredients, ${ }^{63}$ so that a package labeled "Peroxide Cream" may have peroxide in a most minute and negligible quantity. ${ }^{64}$ The statutory exceptions as to blends and distinctive names have permitted the use of labels not completely truthful. ${ }^{05}$ The container may be shaped, colored or dressed in any way desired without liability; ${ }^{6 B}$ yet more deception as to quantity, quality, size or contents may result than from any possible label. In the field of therapeutic representations, a fine line between "remedy" and "cure" has been drawn although as often as not the gullible purchaser has been deceived in both instances; ${ }^{67}$ and the label may contain the most puffed and ridiculous statements. ${ }^{68}$

${ }^{\infty}$ Such is apparently the legal effect of Weeks v. U. S., stipra note 5, save when the product is offered for sale under the name, or as an imitation of, another article. Cf. Reg. 15 (When Label Required).

${ }^{\infty}$ See Savage v. Jones, supra note 4, at 531, 32 Sup. Ct. at 725; Newton Tea \& Spice Co. v. U. S., supra note 36 , at 480 . For the list of drugs, see note 25 , supra.

"See Rep. Sec. Agr. (1920) 52; Chase \& SchlinK, op. cit. supra note 56, at 47. For the failure of the Act to reach a new poison, see Thallium Poisoning (1932) 98 AM. MEd. AssN. J. 406.

"See U. S. v. 65 Casks, Liquid Extracts, supria note 9; cf. Reg. 24 and 25 and the provisions of the Act, supra note 25.

${ }^{6}$ In re Wilson, $x 68$ Fed. 566 (C. C. D. R. I. 1909); U. S. v. Boeckmann, I76 Fed. $3^{82}$ (C. C. E. D. N. Y. I9xo); cf. Lexington Mill \& Elevator Co. v. U. S., 202 Fed. 615 (C. C. A. 8th, x913), aff'd on other points, 232 U. S. 399, 34 Sup. Ct. 337 (1914). On statements as to weight, measures and counts in packaged goods, cf. Reg. 26 and U. S. v. Shreveport Grain \& Elevator Co., supra note 26.

ot U. S. v. Am. Druggists' Syndicate, supra note 29.

${ }^{\infty}$ Illustrative are U. S. v. 68 Cases, Syrup, 172 Fed. 78I (E. D. Ill. I909) ("Blended Syrup-made by $X$, Blender of Fancy Maple Syrup and Maple Sugar" not misleading though no maple syrup); U. S. v. Blanke Tea \& Coffee Co., N. J. No. 2797 (E. D. Mo. 1913) ("Mojav Coffee . . . A special blend of good drinking coffee" not misleading as indicating blend of Mocha and Java coffces though product almost entirely of Santos coffee); U. S. v. Ten Cases, Bred Spred, 49 F. (2d) 87 (C. C. A. 8th, 1931) (Strawberry "Bred Spred" not indicative of strawberry jam). An averment that a defendant branded an article with a label correctly describing it but intending the public or purchasers to understand something else fails to state a violation. Nave-McCord Mercantile Co. v. U. S., I82 Fed. ${ }_{4} 6$ (C. C. A. 8th, 1910).

${ }^{\infty}$ Rep. Sec. Agr. (r920) 52; Yearbook, Dept. Agr. (1928) 405; Rogers, Good Will, Trade-Markss and UNFarR Trading (1919) x94. For the protection given by the Federal Trade Commission in instances of false packaging, sec Publfe Regulation of Competimive Practices (Nat. Ind. Conf. Bd., 1929) 147149.

${ }^{67}$ Cf. U. S. v. Natura Co., 250 Fed. 925 (N. D. Cal. 1917); Simpson v. U. S., 241 Fed. 84 I (C. C. A. 6th, 1917). A similar disregard of the effect on the consumer has resulted from a too strict application of the ejusdem generis doctrine to therapeutic representations. Cf. Chichester Chemical Co. v. U. S., supra note 53 .

"Some courts seem entirely too content with a "commercial" standard of truth, piously hoping that the purchaser will not be so gullible as to be deceived by the depicted panaceas. "This label is as close an adherence to the truth as is customary in commercial labels, and speaks the truth as nearly as would be expected of any advertiser of a commercial product ... [many of the claims] are so extravagant as to justify the characterization of being ridiculous. No trial judge is in a position to pit his judgment of the benefit to the seller of certain commercial practices against the judgment of commercial men." Dickinson, J., in U. S. v. 94 Dozen Bottles, Capon Spring Water, supra note 9, at 380, 382. On such puffed advertising in even reputable medical journals, see Harding, FAds, FraUds, aNd Physictans (x930) c. vir. 
One ingenious bottling concern lauded to the skies the therapeutic values of its spring water and successfully defended its label on the ground that any water if drunk liberally had these same values! ${ }^{69}$

Unfortunately, too, because of the law's definition of a "drug" as something used for disease, ${ }^{70}$ all kinds of cosmetics, powders, and depilatories may be palmed off on an unsuspecting public and, not being foods or drugs, completely escape both the misbranding and the adulteration provisions, unless their promoters, unguided by counsel, inadvertently place therapeutic statements as to "disease" on the label. ${ }^{71}$ Therapeutic mechanical devices, ray machines, and "health" lamps are likewise not reached by the Act. ${ }^{72}$ And since obesity is not strictly a disease, the market has been flooded with pills, salts, salves, and ointments hailed with most pretentious claims as to reduction of weight and having the most dubious, if not injurious, results. ${ }^{\mathbf{7}}$

\section{Misbranding UNDER the Bill}

The bill bravely attempts to remedy all the defects indicated, and the result is an exceptionally comprehensive and complete control. Its remedial effort pushes along various directions-by its enactment a host of new articles would be by a legislative swoop brought within the Act, new affirmative duties of truth telling would be imposed in addition to strengthening of older prohibitions, and the label would cease to be the federal fulcrum of activity. Some of the changes which at first glance seem radical departures will be seen on inspection to be but clarifications of the present

${ }^{20}$ U. S. v. 94 Dozen Bottles, Capon Spring Water, supra note 9.

${ }^{70}$ Section 6 of the Act provides that the term drug includes all medicines and preparations recognized in the United States Pharmacopoeia or National Formulary and any substance "intended to be used for the cure, mitigation, or prevention of disease of either man or other animals." An inhalant may be a drug under the Act. United States v. II Cartons, Drug, etc., supra note 25. Most state statutes repeat the federal definition. Seo I Dunn, op. cit. supra note 2, passim. But cf. Okin. Comp. Stat. Ann. (Harlow, 193I) $\$ 4540$ ("care, protection or prevention of disease"). The Canadian and English definitions are similar to that in the federal Act. Cf. Rev. Stat. Can. (Ig27) c. 76, \$2 (c); I8 \& I9 Geo. V, c. 3I, \$34. On what is a "proprietary or patent medicine" under state laws, see Ferguson v. Arthur, II 7 U. S. 482, 6 Sup. Ct. 86I (1886); State v. Jewett Market Co., 209 Iowa 567, 228 N. W. 288 (r929); Note (1932) 76 A. L. R. 1207. For a review of the present deficiencies of the Act in regard to drugs, see Cramp, Patent Medicines and the Law, AMr. MERCURy, Nov. 1933.

${ }^{72}$ Rep. Sec. Agr. (1913) I8; See Harding, The Constumer and the Medicine Cabinet, J. Home Econ. (July, 1930) 558, 560; KalletT \& Scrilinx, I00,000,000 GuineA PIGs (1933) c. V; Beauty at Cost (Dept. Agr., Aug. 28, r933). The Federal Trade Commission does some work in regard to misleading advertisements of cosmetics. See Public Reguration of Competitive Practices, supra note 66, at ioz-127. For special problems arising in connection with antiseptics, see FAKE ANTISEPTICs AND THE LAW (F. and D. Adm., 1930); (1929) 93 AM. MED. AssN. J. 1225; Note also the particular mention of antiseptics in the statutes cited infra note 79. KaLLETT \& SchLINK, op. cit. supra, c. VI. Therapeutic statements on the label as to disease would make the cosmetic automatically a legal drug (see Harding, supra), just as, when curative claims are advanced as to water (classified as a food under the Act), water may be proceeded against as a drug. Bradley v. U. S., supra note 53; Goodwin v. U. S., 2 F. (2d) 200 (C. C. A. 6 th, I924). Cigars and cigarettes are also not within the Act despite frequent semi-therapeutic advertisements. For a criticism of such advertisements, see (1930) 94 AMr. MED. Assn. J. 810. But once a preparation is declared a drug, it is fully subject to the Act's requirements for drugs even though prima facie such requirements seem inapropos. U. S. v. Ix Cartons, Drug, etc., supra note 25.

${ }^{73}$ Rep. SeC. Agr. (1930) 56; Contraptions or Cures (Dept. Agr., Aug. 28, 1933).

${ }^{73}$ ReP. SEC. Agr. (I920) 52; see Harding, What the Food and Drtug Administration Does (1930) 15 ScIENTric MonthLy 522, 524. For a striking illustration of dangerous obesity "cures," see (I93I) 97 AM. Med. Assn. J. 3555 . 
state of the law; many are wholly new. The description of the bill's effect is further complicated by the fact that to some extent, at least, the misbranding features of the bill have been employed with a view toward stopping certain types of adulteration. ${ }^{74}$

New articles are included. Cosmetics would appear for the first time in a federal regulatory statute. ${ }^{75}$ As defined, it includes all substances and preparations intended for cleansing, or altering the appearance of, or promoting the attractiveness of, the person. $^{76}$ The definition seems broad, yet comparison with the definition of cosmetics made in the Retail Code ${ }^{77}$ under the National Recovery Act would seem to indicate that the bill's definition may not cover many lotions, soaps, and powders used for "refreshing" the person. It is not impossible, however, that these as well as many cosmetic preparations clearly included within the bill are covered by the bill's broader definition of a drug. ${ }^{78}$ It is interesting to note that despite the widespread use of cosmetics only some six states, Hawaii, and the District of Columbia appear to have food and drug statutes subjecting them to control. ${ }^{79}$ In each case hitherto the method of subjection has been by considering the cosmetic as a technical "drug." The effect of the bill's not placing cosmetics similarly in the drug class will be the subject of later consideration in this article. ${ }^{81}$

But drug is now to include "all substances and preparations, other than food. . . . intended to affect the structure or any function of the body of man or other animals." ${ }^{2}$ In other words, the anti-obesity hokums and the nostrums advertised. for

${ }^{74}$ Cf. BrLl, $\$ \$ 7$ (d), 7 (e), 8 (g).

${ }^{75}$ For the' extent to which the present bill controls cosmetics, see infra, p. 105. The Associated Manufacturers of Toilet Articles have objected to the inclusion of cosmetics with drugs on the ground that their products would thereby be brought within the purview of state pharmacy laws. See Summary of Conference with Drug Trade Representatives, April 27, 1933, at 3.

${ }^{30}$ BiLL, $\$_{2}$ (c).

"Schedule "A," Section I (5), reads "Cosmetics and Toilet Preparations-The term cosmetics and the term toilet preparations as used herein shall mean toilet articles and perfumes, toilet waters, face powders, face creams, rouges, shaving creams, dentifrices, soaps and similar substances and preparations designed and intended for application to the person for the purpose of cleansing, improving the appearance of, refreshing or preserving the person." Contrast with this the restricted character of "cosmetics" as used in the Tariff Act of 1922, 42 STat. 858 (1922), 19 U. S. C. A. \$121, sched. 1, par. 62.

${ }^{78}$ Cf. Bill, \$2 (b) (3).

${ }^{70}$ Cat. Pen. Code (Deering, r93I) \$383; IND. Ann. Stat. (Burns, 1926) \$2655; Wis. Stat. (x93 \$352.01; N. D. Comp. Laws ANn. (Supp. I925) 2889b 4. ("The term 'drug' as used in this act shall include all medicine for internal or external use, antiseptics, disinfectants, washes, perfumes, and cosmetics."); Orno GeN. CODE (Page, r931) $\$ 5775$ ("The term 'drug' as used in this chapter, includes all medicines for internal or external use or inhalation, antiseptics, disinfectants and cosmetics"); W. VA. CoDE (1932) c. 16, art. 7, \$1 (Drug "shall include all medicines for internal or external use, antiseptics, disinfectants and cosmetics"); HawaIr Rev. Laws (1925) c. 76, $\$ 993$ ("The term 'drug' as used in this chapter shall include all drugs, medicines, or medical preparations for external or internal use, antiseptics, antiseptic dressings, disinfectants and cosmetics"); D. C. CODF (I929) tit. 20, \$1222 ("The term 'drug' as used in this act, shall include all medicines, for external or internal use, antiseptics, disinfectants and cosmetics").

${ }^{80} \mathrm{Cf}$. the statutes cited supra note 79.

${ }^{81}$ See infra, p. Ir8.

${ }^{2}$ BrLL, $\$ 2$ (b). The bill's definition of drug changes "medicines and preparations" in the U. S. P. or N. F. [Act, §6] to "substances and preparations." The bill's definition also includes substances and preparations in supplements to the Pharmacopoeia and Formulary official at the time of the introduction of the drug into interstate commerce. On the validity of this indirect delegation of power to private 
general health rather than strictly disease purposes are to lose their immunity. The exclusion of food from the definition seems necessary to prevent every article of food coming within the category of the new "drug." On the other hand, the exclusion might prove to be a most dangerous loophole as by cleverly advertising as foods, the anti-obesity pills, yeasts, and tablets may be given new leases of legal longevity. This result could have been avoided by having the purpose for which a product was manufactured, dispersed, sold, or offered for sale determinative of its character. ${ }^{83}$

Finally, the quacks and the fakes who have preyed upon sufferers from such diseases and ailments as rectal cancer, goitre, asthma, diabetes, etc., by selling them fake belts, machines, straighteners, exercisers, and similar devices would find their articles of trade under the federal law. Under the provisions of Section 2 of the bill, the term "drug" includes two types of devices: those intended for use in the cure, mitigation, treatment, or prevention of disease, ${ }^{84}$ and those intended to affect the structure or function of the body. ${ }^{85}$ Devices for cleansing, altering the appearance of, or promoting the attractiveness of the person are apparently not included, but since the fake contraptions will frequently accomplish the beautification objects by affecting structural or functional changes, many of them would be within the new Act's condemnation.

Sections 6,7 and 8 of the bill set forth the new commandments on the subject of misbranding. Section 6 is devoted to misbranding in general. Under its provisions, a food, drug, or cosmetic is to be deemed misbranded:

(a) if its "labeling is in any particular false, or by ambiguity or inference creates a misleading impression regarding any food, drug, or cosmetic"; 86

(b) if in the case of packaged goods, its label does not contain the name and place of business of the manufacturer, packer, seller, or distributor, as the case may be, together with an accurate statement of weight, measure, or numerical count as prescribed by regulations of the Secretary of Agriculture; ${ }^{87}$

groups of citizens, see Note (1932) 32 CoL. L. Rev. 80. For a history of pharmacopoeias, see La Wall, Four Thousand Years of Pharmacy (1927). The definition adds also the word "treatment."

The definition of food as given in the bill in Section 2 (a) expressly includes substances and preparations entering into the composition of food, drink, confectionery or condiment. Cf. Act, $\$ 6$. The change secms only to read into the law the result of the Hipolite Egg case, supra note 8. The bill's definition seems modeled on the English law. Cf. I8 and Ig GEo. V, c. 3I, \$34. As to what are "foods" within the statutory definition, see Note (I922) 17 A. L. R. 1282. Tobacco is probably not within the scope of the bill. Cf. State v. Ohmer, 34 Mo. App. 124 (1889), and note 7r, supra.

${ }^{3} C f$. DeL. Rev. Code (1915) c. roo, $\$ 80$. With the exception indicated in the text, the definition of foods, drugs, and cosmetics are not to be mutually exclusive. Brit, \$2(c). Neither are they exclusive under the present Act. Cf. U. S. v. 94 Dozen Bottles, Capon Spring Water, supra note 9.

st Brul, \$2(b) (2).

Id. $\$ 2$ (b) (3).

${ }^{\text {so }} \mathrm{BrLL}, \$ 6(\mathrm{a})$. Cf. IIl. "Rules for Labeling. \$7. Deceitful and suggestive names and designs shall not be used. No design presenting a superior ingredient, its source or a process of its manufacture, shall appear on the label unless the inferior ingredients are likewise so represented in an equally prominent manner."

${ }^{87} \mathrm{BrLl}, \S 6(\mathrm{~b})$. The authority to make reasonable variations as to weight and count, and exemptions as to small packages is repeated. Id. The exemption as to small packages when permitted by the Secretary of Agriculture does not extend to small packages of drugs. Id. The Secretary may exempt classes of 
(c) if data required on the label to avoid adulteration or misbranding under any of the provisions of the bill are not so conspicuously placed as to be easily seen and so phrased as to be readily intelligible to the purchaser or user under customary conditions of purchase and use. ${ }^{88}$

Section 6 (a) must be read in conjunction with the definition of "labeling"89 given earlier in the bill which as defined includes both labels "and other written, printed, and graphic matter, in any form whatever accompanying any food, drug, or cosmetic." Such a conjunctive reading indicates that the Sherley Amendiment in respect to circulars and pamphlets within the package is herewith extended to all articles covered by the bill-foods and cosmetics as well as drugs-and to all types of misrepresentation. The present clause is unambiguous: physical detachment from the package is not to confer a privilege to dupe the consumer.

An interesting question arises as to whether subsection (b) has not gone even beyond the terms of the Sherley Amendment. That amendment succeeded in reaching the detached circulars by providing that the drug article was to be misbranded if its package should "bear or contain" the false and fraudulent statements. The definition of "labeling" as given in the bill eschews this terminology; under its broad language the law now is to affect all literature which in any way may be deemed as "accompanying" 90 the interstate package. In view of the bill's definition of "advertisement" 91 placed in juxtaposition to that labeling and expressly excluding "labeling," evidently representations in media remote from the package are not included. Not so patently, however, is "labeling" confined to the world within the package, and it is not unlikely that under the technical definition of "labeling" will come such methods of representation to the public as placards, signs, and showcards placed in proximity with the package and possibly also representations affixed to racks, trays, and showcases in which the packages are placed for display on retail sale.

canned goods from the requirement of noting the numerical count or weight during transportation, in accordance with trade practice, to establishments for labeling. Such transportation would not otherwise be permitted. Cf. notes 9, ro, supra. Under the present Act, \$6, the Gould Amendment as to weight and numerical count applies only to packaged foods. The bill extends the provision to packaged drugs and cosmetics.

Under the wording of Section 6(b) of the bill, the requirement for disclosure of name and place of business may be satisfied by giving those of the manufacturer, packer, seller, or distributor. Semble, where an article is manufactured by $A$ and sold by $B$, the label need not have both the name of $A$ and $B$. Cf. Irr. REv. Star. (Cahill, I933) c. 56b, \$9 (4). Accordingly, the provision seems easy of evasion by the use of dummy distributing companies. It is interesting to note that comparable state statutes insist upon "the name of the real manufacturer, jobber, etc." Cf. CaI. GEN. LAws (I931), Act 57, No. 6(5); Nev. Comp. Laws (Hillyer, r924) \$6188 (5); N. D. Comp. Law (Supp. 1926) \$2289b 6; 2 OkLa. CoMp. Stat. ANN. (Bunn 192I) c. 79, $\$ 8838$. These statutes expressly require the name and place to be stated in clear and distinct English words in legible type. Canada deems a packaged food or drug misbranded if the label bears the name of an individual or of a company elaimed to be the manufacturer or producer of the article which individual or company is fictitious or nonexistent. CAN. Oro. IN C. (1928) 57 , The only requirement in the present Act for disclosure of source is that of the place or manufacturer or production in the exceptional case of mixtures and compounds seeking the statutory "distinctive name" immunity. ACT, $\$ 8(4-\mathrm{I})$. Some states provide for special labeling of "soaked or bleached" canned goods. See, e.g., Mich. CoMp. Laws (1915) c. $124 \$ 6487$, §14.

${ }^{83} \mathrm{BILL}, \$ 6(\mathrm{c})$.

${ }^{\circ}$ BILI, \$2(i).

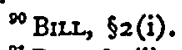


The subsection under discussion does more than add to the list of media; it lays strong hold upon those whose chief stock in trade is criticizing the competitor's wares. For note that under the wording of subsection (a) misbranding occurs if the labeling on a food, drug $_{2}$ or cosmetic is false or creates a misleading impression regarding "any food, drug, or cosmetic." ${ }^{2}$ That the bill here creates a statutory crime of trade libel and disparagement of goods appears more evident if this labeling section be contrasted with the definition in the present Act and that given in the bill of false advertising of a food, drug, or cosmetic as occurring when the advertisements thereof are false regarding "such food, drug, or cosmetic." 93 The change is important. The provision is also novel. Under the present Act, United States v. Johnson ${ }^{94}$ is still a controlling authority for the point that the present federal law despite its broad terms aims solely at misrepresentations as to the identity, quality, or composition of the article itself, and is not concerned with what lies the label or the circulars may make regarding other products in fields either vertically or horizontally competitive.

The phrase of the labeling clause which seems to have captured public attention and to have received not a little criticism is that which recites that misbranding occurs where the labeling "by ambiguity or inference creates a misleading impression." ${ }^{05}$ Similar language appears in the bill's definition of false advertising. ${ }^{96}$ Several problems and difficulties readily come to the fore. Suppose the statements on A's label create false impressions not in the minds of consumers or purchasers generally but on special classes of such persons? Suppose the label conveys the full truth in one geographical section of the country but creates false impressions in another? Consider also the situation where A's labeling by itself is not misleading but creates a false impression because of:

(I) statements made by $A$ on other labels of the same product;

(2) statements made by $A$ on labels of other products;

(3) statements made by B. (e.g. a trade association) regarding the product. The indications are that in all the cases suggested a misbranding occurs. ${ }^{97}$ This conclusion is supported by the broad language of the bill and a number of decisions. As a matter of fact, the term "misleading" in the present Act has been interpreted as including the creation of a "false impression" so that decisions thereunder are relevant and point somewhat to this conclusion.

In United States v. American Laboratories, ${ }^{98}$ the defendant had marketed a product called "Bad-Em Salz." The statements made concerning the product were technically true, but because of the belief prevalent among many people that Carlsbad or Bad-Ems waters had medicinal property, the product was seized as misbranded. The defendant argued that since the statements were strictly true they were not false

22 BILL, §6(a).

"3 Brz, $\S_{9(a)}$. The misbranding provision of the bill contrasts also in this respect with the present Act. Cf. Acr, $\$ 8$ ("Statement, design, or device regarding such articles"). Its primary purpose was to cover false claims for other products sold by the same manufacturer.
os Supra note 50.
${ }^{85}$ BIII, $\$ 6(a)$.
${ }^{\text {"See infra note } 102 .}$
'Id. $\S 9$ (a).
${ }^{23} 22$ Fed. 104 (E. D. Pa. 19r5). 
or misleading within the meaning of Section 8 of the present Act, and as the result claimed to follow from the use of the medicine was a matter of opinion there was no basis for the charge. The court denied the contention and said:

"It is not a necessary condition of a finding of guilt that the statement of what the drug is should be a statement flatly and baldly false but that the word 'misleading' in the act has its function, which is to bring the statement within the inhibition of the statute if it is such as to create or lead to a false impression in the mind of the reader as to what the ingredients or the composition of the drug are."90 (Italics ours).

Again, under the present Act, using the term "Extra Dry Champagne" on a label affixed to a bottle with a foreign "dress" has been held a misbranding on the ground that the combination created in the mind of the consumer "the impression that they were purchasing a foreign and not a domestic product."100 Under the present Act also a departmental regulation provides that an article so labeled as to convey the impression that all of the ingredients are declared is misbranded if the list be incomplete. $^{101}$

The "impression" phrase is therefore no radical innovation in the law of food and drug control. Moreover, under the "unfair trade" provisions of the Federal Trade Commission Act, the Federal Trade Commission has issued cease and desist orders not only where direct falsehood has been used as a competitive weapon but also where the advertising or label created false impressions because of circumstances extrinsic to the censured publicity. ${ }^{102}$ That the law within recent years has been moving into the field of "puffing," hitherto so sacrosanct in public and private law, is attested also by a number of state statutes prohibiting the use of terms suggestive of falsehood. ${ }^{103}$ The constitutionality of the clarification of the present law as respects false impressions, or of the extension if it be such, cannot be seriously questioned. ${ }^{104}$

${ }^{50} \mathrm{Id}$. at 108.

${ }^{100}$ Schraubstadter v. United States, supra note 44.

${ }^{101}$ Cf. Reg. I4(h). See also U. S. v. Johnson, supra note 50, at $498,3 x$ Sup. Ct. at 628 .

${ }^{203}$ Royal Baking Powder Co. v. F. T. C., 4 F. T. C. I (I92I), $a f^{\prime} d, 28 I$ Fed. 744 ( C. C. A. 2d, 1922). The court deemed a change from a cream of tartar baking powder widely advertised as such to a phosphate baking powder as an attempt to sell an inferior product "under an impression" caused by the prior advertisements, which "impression" came under the Commissioner's censure though the phosphate advertising was literally true. Id. at 753. For the background of this particular deception, see Chase ez Schunk, op. cit. stpra note 56, at 150. Cf. also Consolidated Book Publishers' Inc. v. F. T. C., 53 F. (2d) 942 (C. C. A. 7th, I931); (1933) 3r Mrar. L. Rev. 804, 8I5.

${ }^{103}$ Thus statutes regulating the organization of coöperative associations forbid the use of "coöperative" in the title of groups not formed under statutes. Similar restrictions exist on the title of eredit unions and banks. Alabama forbids auctioneers to employ cappers or boosters to raise bids. See Note (1930) 43 Harv. L. Rev. 945, 948 n. 28-34. See also, W. Va. Rev. Code (Michic, 1932) $\$ 1370$ (6) (8) (article deemed misbranded "if it is sold under a coined name and does not contain some ingredient suggested by such name or contains only an inconsiderable quantity"). Cf. CAN. Rev. Stat. (1927), c. 76, 58(3) (compounds and imitations must be so labelled "as not to be likely to deceive").

${ }^{{ }^{20}}$ In Jasnowski v. Connolly, 192 Mich. 139, 158 N. W. 229 (1916), a "Printers' Ink" statute was attacked on the ground that while proper for the legislature to score false advertising, it could not prohibit "deceptive" advertising as what might give $A$ an erroneous impression might not tend to deccive $B$. The statute was upheld. The libel which was sustained in Seven Cases of Eckman's Alterative, supro note 29, charged, inter alia, that "the statement 'we know it has cured' and that 'it will cure tuberculosis' is false. 
The general provision that the labels of all articles within the compass of the bill if in packaged form recite the name and place of business of the manufacturer, seller, or distributor and give an accurate statement of the quantity but foreshadows and indicates what is one of the outstanding contributions of the bill-the duty to reveal the truth on the label as contradistinguished from the present frail duty (except in special circumstances) not to place mendacious statements upon the label. The deception which resulted from the failure of the present law in general to demand a standard higher than "do not lie" has already been noted. Under the bill, if enacted, no longer could the adroit vendor put on the market a food or drug package embellished with pretty colors and fancy design and pleasant trade name but with a complete failure actually to disclose and indicate more concretely just what is the nature of the product. Nor would shipment across state lines without labels in order to affix deceptive labels within the state of destination succeed as an evasive manoeuver.

Sections 7 and 8 of the bill are clear in their import. Food labels from the enactment of the bill must:

(I) give the name of the food in terms defined by regulations fixing the identity of the product if the food purports to be or is represented as such a food; ${ }^{\mathbf{1 0 5}}$

(2) state the standard of quality of the food if the food purports to be or is represented as a food for which regulations have been prescribed both fixing such standard and requiring a statement of the standard; ${ }^{\mathbf{1 0 6}}$

(3) give the common name of the food if any and the common name of each ingredient in order of predominance by weight if no definition of identity has been made by the regulations, and in addition such other information as the Secretary of Agriculture may deem necessary to protect the public from deception. ${ }^{107}$

In similar fashion, an analysis of the terms of the bill shows that drug packages must have labels which:

fraudulent and misleading in this, to wit, that it conveys the impression to purchasers that said article of drugs will cure tuberculosis." Id. at 514,36 Sup. Ct. at 192 . The "impression" test is also used in the "Federal Reserve Bank Act, 44 STAт. 628 (19'26), I2 U. S. C. A. $\$ 586$ (no bank, banking association or trust company not a member of the Federal Reserve system shall ". . . publish or display any sign, symbol, or advertisement reasonably calculated to convey the impression that it is a member of such system."). Cf. N. R. A. Code for Petroleum Industry, Rule 25 ("implication which leads to a false or incorrect conclusion"); Advertising Review, Code of Advertising Practices ("false statements or misleading exaggerations," "indirect misrepresentation of a product or service through distortion of details, either editorially or pictorially").

${ }_{105}$ BiLl, $\$ 7$ (d).

10s Id. $\$ 7(\mathrm{e})$. It is important to notice that the purporting or representing to which the bill refers need not be made upon the label or the package. The article will be subject to these affirmative disclosure requirements if the representation be made orally, by advertisements or atherwise. $C f$. Weeks v. U. S. supra note 5. On the nccessity for the affirmative disclosure, see Must the Hotssewife Beware? (DEpr. AGr. Aug. I8, 1933); Barber, Are Foods Truthfully Labelled? (1933) Ir Hygeia 597.

${ }_{10 \tau}$ Birl, $\$ 7(\mathfrak{f})$. For an analogous broad power of an administrative body to compel statements deemed by it necessary or appropriate in the public interest, see National Securities Acr, \$10 (3). It should be carefully noted that the disclosure of ingredients in the case of foods is restricted to (3) above. This seems ignored in many trade journal discussions of the bill. For opposition to the disclosure even in this instance, see Jordan, CONFECTIONER's J., Nov, I933, 28. 
(I) indicate the quantity or proportion of some sixteen narcotic substances or their derivatives contained therein in a form prescribed by the regulations, the name of such narcotics, and in juxtaposition with the name and statement of composition the words: "Warning-May be habit forming"; 108

(2) state the quantity or proportion of ethyl alcohol, ethyl ether, or chloroform present in the drug; $;^{109}$

(3) state the common name of the drug, if any there be, and the name and quantity or proportion of each medicinal or physiologically active ingredient in the case of all drugs whose name is not the same or imitative of names in the United States Pharmacopoeia or National Formulary or supplements thereto; ${ }^{110}$

(4) give such statements as are required by the above mentioned Pharmacopoeia or National Formulary where its name is the same as, or simulates the name of drugs defined in, those volumes; ${ }^{111}$

(5) give precautions where the drug is liable to deterioration and the Secretary of Agriculture so directs; ${ }^{112}$

These provisions as to disclosure required on the label are the more remarkable if it be noted that, under the bill, the "label"113 means both that on the immediate container and also that on the outside container, if any there be, of the retail package. Possibly the proposed law would be satisfied if the disclosure be made on either type of label; but such a construction would move contrary to the design of the draftsmen of the bill to afford the consumer a maximum of protection. Two further disclosures must be made as to certain drugs, but these may be made in the "labeling" and not necessarily on the "label." If a drug is not a pharmacopoeia preparation, its labeling

\footnotetext{
${ }^{103}$ BrLL, $\$ 8$ (b). This subsection applies only where the drug is intended for internal use and hence will not apply to inhalants. Cf. U. S. v. II Cartons, Drug, etc., supra note 25 . $\$ 8$ (b) omits alcohol, chloroform and acetanilid from the prior list of drugs so that drugs containing them need not give the habit-forming warning. But see note 109, infra. To the ten drugs now covered by the Act (see note 25, supra), the bill adds barbital, bromal, carbormal, coca, chloral (Act has chloral hydrate), paraldehyde, peyote, and sulphonmethane. Where derivatives are present, the name both of the derivative and the principal drug must be given. That the present list of drugs has proved antiquated is indicated by state statutes which have added to the federal list. See, e.g., Colo. Ann. Stat. (Courtright, I930) c. 1, 87 (2) (any harmful coal tar derivative); Idafo Comp. Stat. (Igrg) \$I6gr (2) (phenacitin); Ind. Stat. ANn. (Burns, r926) \$8228 (phenacetine, antipirine); Mo. ANN. Code Bagby, I924) art. 43, § 92 (holocaine, novocaine, alypin, codeine, antifebrin, acetphenetidin, phenacetine, antipyrine); Nen. Comp. Stat. (I929) $\$ 81-904$ (phenacetine, antipyrine, belladonna); N. J. Comp. STAT. (Supp. r924) \$81-4 (acet-phenetidinc, phenacetin, antipyrin); N. D. Comp. LAws (Supp. 2925 ) \$2889b6 (any narcotic or habit-forming drug); PA. Stat. (Supp. 1928) \$9340 (phenacetine, antipyrine). On the general legal development of the Harrison Narcotic Act, see Note (1928) 13 CoRN. L. Q. 627.

${ }^{100}$ BrLL, $\$ 8$ (c). This provision applies to inhalants as it is not prefaced by the words "if it is for internal use." But the bill fails to have any analogous provision for foods. The declaration of ethyl cther is wholly new.

${ }^{110} \mathrm{BILI}, \$ 8$ (c). Note the limited class of drugs to which this disclosure of ingredients applies.

111 BiLl, $\$ 8$ (f).

12 BrIL, $\$ 8(\mathrm{~g})$. The Secretary is authorized after notice and hearing to designate which drugs are liable to deterioration.

113 BiLl, \$2 (h). But the "label" of the bill does not include pamphlets within the package. Cf. $\$ 2$ (h) and $\$ 2$ (i). The affirmative disclosure provisions, therefore, will not be satisfied by recitals made in such pamphlets.
} 
must contain "complete and explicit directions for use."113* If the drug purports to be or is represented as a germicide, bactericide, disinfectant, or antiseptic, its labeling must state each use and, plainly and conspicuously and in juxtaposition therewith, the method and duration of application necessary to kill micro-organisms. ${ }^{144}$

We may postpone the question of the constitutional validity of the disclosure provisions to the extent that the question is affected by the delegation to the Secretary of Agriculture of the power to make regulations. ${ }^{115}$ What is first pressing is whether or not the federal government may compel such disclosure. The source of federal authority is, of course, the commerce power and the much mooted collateral power thereunder to make "police" regulations regarding the products which are the subject of interstate commerce. The bar to the unrestrained exercise of that power is the due process provision of the Fifth Amendment. The property rights which the disclosure provisions invade may be in many cases not only trade secrets and trade formulae but also the more general right to retain present labels and trademarks, to continue present methods of distribution and the good will incident thereto, and to be spared the printing expenses and other costs which the disclosure will necessitate. ${ }^{116}$ This latter may not be inconsiderable if it be observed that to meet some requirements of the statutory disclosure, qualitative analyses of the product must be made, and made recurrently. 117

Fortunately, legal decision on the point is not wanting. The very necessity for a federal law demanding that more information be given to the consumer as to what he buys and that such information be more than puffing and hokum has been presaged by the increasing number of state statutes which have insisted on affirmative labels as to the ingredients of various products ranging from gasoline and fertilizers to cold storage eggs and artificially flavored soft drinks. ${ }^{118}$ And the decisions dealing with these statutes run to the effect that compulsory disclosure of the ingredients of the food or drug and the standard of their quality may be demanded without violating the due process inhibition. Thus in Corn Products Refining Company v. $E d d y,{ }^{110}$ pursuant to the Foods and Drugs Law of Kansas and regulations ${ }^{120}$ adopted

${ }^{1132}$ BIIL, 58 (d). The Secretary is empowered to exempt drugs by regulation from the requirements of this subsection. Note its relation to $\$ 4$ (a). It excludes germicides, antiseptics, etc., which are subject to subsection (i).

${ }^{214}$ BiLl, $\$ 8$ (i). The definition seems too rigorous. For the present difficulties in regard to antiseptics, see supra note 7I. Under subsection (i) drugs are not misbranded if the germicide, bactericide, disinfectant, or antiseptic is represented as intended for specific kinds of micro-organisms only and the labeling states conspicuously and in juxtaposition the method and duration of application to kill these kinds.

215 See infra p. I07.

${ }^{116}$ Sec Drug Trade News, Oct. I6, I933, at 26, 55; id. Nov. 13, I933, at 35.

197 But Section 26 (a) of the Bill provides that its effective date shall be six months after the date of approval. In many instances, the six months period should be sufficient time in which to alter distribution methods.

${ }^{213}$ See supra note 103.

${ }^{110}$ Supra note 4 .

123 The regulation involved provided as follows: "Manufacturers of proprietary foods are required to state upon the label the names and percentages of the materials used, so far as is necessary to secure freedom from adulteration and misbranding: ( $I$ ) In the case of syrups, the principal label shall state 
under it, the State Board of Health had notified the plaintiff corporation's agents that unless they stated, on the label placed on its product, the percentage of each ingredient of which it was composed, they would be arrested and prosecuted. The corporation manufactured a proprietary table syrup composed of corn syrup or glucose, molasses and sorghum. The plaintiff sued to enjoin the enforcement of the law, alleging its unconstitutionality. The Supreme Court of the United States held for the defendants in an unanimous opinion.

"It is, however, urged that since plaintiff's syrup is a proprietary food, made under a secret formula and sold under its own distinctive name, and since it contains no deleterious or injurious ingredients, the effect of the regulation in requiring plaintiff to disclose upon the label the ingredients and their proportions amounts to a taking of its property without due process of law. Evidently the purpose of the requirement is to secure freedom from adulteration and misbranding; the mischief of misbranding being that purchasers may be misled with respect to the wholesomeness or food value of the compound. And it is too plain for argument that a manufacturer or vendor has no constitutional right to sell goods without giving to the purchaser fair information of what it is that is being sold. The right of a manufacturer to maintain secrecy as to his compounds and processes must be held subject to the right of the State, in the exercise of its police power and in the promotion of fair dealing, to require that the nature of the product be fairly set forth."121

Legislation requiring disclosure of ingredients on the label or to executive officers, has been upheld by the state and federal courts. ${ }^{122}$

It should be observed that the present bill is worded similarly to the Kansas regulation. It also compels in the instances noted a statement of the quantity or proportion of various ingredients and thus storms the sanctum of the trade formula. But Corn Products Refining Company v. Eddy. would seem decisive. In an earlier case $^{123}$ before the Supreme Court the Court had before it a state statute requiring manufacturers of mixed paints to label the ingredients composing them. The man-

definitely, in conspicuous letters, the percentage of each ingredient, in the case of compounds, mixtures, imitations, or blends. When the name of the syrup includes the name of one or more of the ingredients, the preponderating ingredient shall be named first."

III. at 431,39 Sup. Ct. at 327 .

Im On labels: Standard Stock Food Co. v. Wright, supra note 4, (name and percentage of diluent); State v. Aslesen, 50 Minn. 5, 52 N. W. 220 (1892), writ of error dismissed per stipulation, 163 U. S. 676 (x895) (names of ingredients of lard substitutes); State v. Buck Mercantile Co., 38 Wyo. 47, 264, Pac. 1023 (I928) (amount of virgin wool); Steiner v. Ray, 84 Ala. 93, 4 So. 172 (1888) (ingredients of fertilizer); Alcorn Cotton Oil Co. v. State, roo Miss. 299, 56 So. 397 (IgIr) (hulls, sawdust, ctc. in cotton seed). To executive officers: Fougera \& Co. v. City of New York, stupra note 4; Crescent Mfg. Co. v. Wilson, 233 Fed. 282 (K. D. N. Y. I916). The interpretation adopted in the latter case that the New York statute required disclosure of ingredients of compounds was not accepted by the New York courts. Cf. People v. Durkee, 189 App. Div. 276, I78 N. Y. Supp. 6r4 (1919); aff'g I0r Misc. 331, I66 N. Y. Supp. 987 ( 1917 ). A statement of ingredients does not compel a disclosure of formula. Savage v. Jones, supra note 4 (Supreme Court refuses to express opinion on constitutionality of formula disclosure). In Patapsco Guano Co. v. North Carolina, IyI U. S. 345, 18 Sup. Ct. 862 (1898), and Armour \& Co. v. North Dakota, 240 U. S. 510,36 Sup. Ct. 440 (1916), the Supreme Court dealt with statutes requiring disclosure of ingredients but the constitutional problem was not considered. In re Ware, 53 Fed. 783 (C. C. D. Minn. I892), the court held that forcible disclosure was possible only when the ingredient was shown to be deleterious. But this contention has been definitely rejected. Cf. State v. Aslesen, supra, and U. S. v. II Cartons, Drug, etc., supra note 25, at 448 .

${ }^{123}$ Heath \& Milligan Mfg. Co. v. Worst, 207 U. S. 338,28 Sup. Ct. II4 (1907). 
ufacturer contended that to meet the terms of the statute it would have to subject each and every can of mixed paint to a chemical analysis prior to the labeling. The Court acknowledged the difficulty but termed it "a burden maybe, but unremediable by the courts-maybe, inevitable in legislation directed against the adulteration of articles or to secure a true representation of their character or composition."124

The constitutionality of the disclosure of some of the other data required is not so clearly established. In particular; the general requirement that foods, drugs, and cosmetics in packaged form must have a label stating the name and place of business of the manufacturer, seller or distributor, may have to run the judicial gauntlet. State statutes requiring that eggs imported from a foreign country be marked "Imported Eggs" and requiring a similarly marked placard at the place of their sale have been held invalid on the ground that there was an insufficient nexus between the place of origin and the character of the product as to require its disclosure. ${ }^{125}$ For similar reasons, a statute requiring on "prepared foods" the true name of the manufacturer and location of factory has fallen, 126 and the requirement of a "Convict Labor" label for goods manufactured in prisons has been held beyond the state's police power irrespective of the question of trespass on Congressional control over interstate commerce. ${ }^{127}$ The insistence on the statement "Irregular Container" for non-standard containers of grapes has been held an unconstitutional attempt to regulate the manner of marketing. ${ }^{128}$ Most of these decisions, however, will not bear the closest examination, and there is a considerable if not equal body of authority holding a forcible disclosure of source to be within constitutional bounds. ${ }^{129}$ In the main, the decisions striking down such forcible disclosure move largely on a false hypothesis: the police power is evoked in food and drug regulation solely to protect the consumer's health. ${ }^{130}$ There has been too little recognition of the fact that food

22x Id. at 359,28 Sup. Ct. at $12 x$.

${ }^{200}$ Ex parte Foley, 172 Cal. 744, I58 Pac. I034 (1916); State v. Jacobson, 80 Ore. 648, x57 Pac. Iro8 (1916) (rested largely on state invasion of interstate commerce).

120 Jewett Bros. \& Jewett v. Smail, 20 S. D. 232, 105 N. W. 738 (1905).

207 People v. Hawkins, 157 N. Y. 1, 5I N. E. 257 (I898); In re Opinion of the Justices, 2 II Mass. 605,98 N. E. 334 (1912). See Note (1925) 25 Cor. L. REv. 814.

${ }^{200}$ Mattei v. Hecke, 99 Cal. App. 747, 279 Pac. 470 (1929). Note also that the bill does not require the place of manufacture or packing to be disclosed but the place of business of the manufacturer, packer, etc. BiLL, $\$ 6$ (b).

${ }^{200}$ In re Bear, 216 Cal. 536, x5 Pac. (2d) 489 (1932) (imported eggs sign); Amos Bird Co. v. Thompson, 274 Fed. 702 (W. D. Wash. I92I) (imported eggs sign; court rests largely on Corn Products v. Eddy, supra note 4); Parrott \& Co. v. Benson, II4 Wash. Ix7, I94 Pac. 986 (I92I) (imported eggs sign); Logan v. Alfieri, 148 So. 872 (Fla. I933) (name of producer on milk containers proper, but other names could not be excluded); People v. Bishopp, ro6 App. Div. 266, 94 N. Y. Supp. 773 (rg05) (names of raiser of cattle, shipper, and point of shipping ); People v. Windholz, 92 App. Div. 569, 86 N. Y. Supp. ror5 (Ig04) (name and place of business on vinegar label, semble proper); State v. Niles, $78 \mathrm{Vt}$. 266, 62 Atl. 795 (Ig06) (name of owner transporting deer on tag). The source disclosure provision appeared in statutes approved in the following cases: City of Chicago v. Schmidinger, 243 Ill. 167,90 N. E. 369 (rgog), aff'd, 226 U. S. 578, 33 Sup. Ct. I82 (1913); State v. Sherod, 80 Minn. 446, 83 N. W. 4I7 (1900).

${ }_{180}$ "A can of corn bearing Jewett's 'Guaranteed' brand would not be relieved of any injurious properties by the mere addition of the canner's name and address." Jewett Bros. \& Jewett v. Smail, supra note 126, at 243, ro5 N. W. at 74x. "It is not claimed that there is any difference in the quality of this 
and drug control is concerned with the protection of the consumer's pocketbook as well as his digestion. Granting, arguendo, that disclosure of source is insufficiently related to problems of health, can the same be said of its relation to the problem of honesty? The fact that incidentally the new Act would give blessing and protection to those who wish to forward the interests of regional products should not condemn a clause whose chief object is to prevent economic fraud.

Provisions other than compulsory disclosure in the misbranding sections remain to be noted. ${ }^{131}$ The law is finally to take direct cognizance that forms of deception other than the verbal may play havoc with the return which the purchaser secures for his dollar. Accordingly, foods and drugs are to be deemed misbranded if their containers are so made, formed, or filled to mislead the unwary purchaser. ${ }^{132}$ The term "container" does not seem to be defined in any section of the bill. The definition of "label," however, refers to both the immediate container of the food, drug, or cosmetic, and the outside container. The inference, despite the absence of definition, would seem to be that the false container prohibition includes both types of receptacles. It is not as certain that "container" would include the "dress" and wrappings about the receptacle. A question may also arise if false coloring of a bottle is prohibited by the provisions of the bill..$^{33}$ In addition to the general requirement of undeceptive containers, a food package will be misbranded if its contents fall below the standard of fill prescribed by regulations of the Secretary of Agriculture, ${ }^{134}$ while drugs whose names are recognized in the United States Pharmacopoeia or National Formulary or any supplement thereto or whose names simulate the names in those volumes must be packaged as prescribed therein, ${ }^{135}$ and drugs liable to deterioration must be packaged as directed by the regulations. ${ }^{130}$

One reads the bill in vain for the statutory-exceptions as to the distinctive names, compounds, imitations, or blends. The protection for imitation food products has been retained where the label bears the word "imitation" in juxtaposition with and in type of the same size and prominence as the name of the food imitated; ${ }^{137}$ in all other respects the statutory exceptions would no longer obtain.

The data of which the bill forces disclosure on the labels of drugs has already been considered. The bill is not satisfied with this important measure of protection but scrubbing brush when compared with one of the same grade or character made outside the prisons." People v. Hawkins, supra note 127 , at $7,5 \mathrm{I} \mathrm{N}$. E. at 258. C . also the reasoning of the courts in the other cases cited supra notes $125-127$.

${ }^{131}$ The bill repeats the present prohibition against offering food and drugs which are imitations or offered for sale under the name of other food or drug articles. Cf. AcT, \$8, with BiLL, \$7 (b), \$8 (h). The only difference is that under Section 8 of the Act the food was misbranded if offered under the "distinctive" name of another food; the bill deletes the word "distinctive." To this extent, the bill has broadened the violation.

${ }^{252}$ BiLl, $\$ 7$ (a-I), $\$ 8(\mathrm{~h})$. Cf. CAN. REv. STAT. (1927) c. $76, \$ 7$ ("if the package is deceptive with respect to design, construction, or fill").

${ }^{233}$ The language of the bill is directed only at the making, forming, and fill of the container.

124 BriL, $\$ 7(\mathrm{a}-\mathrm{I})$.

${ }^{235} I d$. $\$ 8$ (f). Drug packaging is, in fact, seldom prescribed in these volumes.

${ }^{130} \mathrm{Id} . \$ 8(\mathrm{~g})$.

${ }^{257} 7 d .57$ (b). 
recites two further special requirements in the case of drugs. First, if the labeling of a drug bear the name of any disease for which the drug is not a specific cure but is a palliative, it must bear in juxtaposition with such name and in letters of the same size and prominence a statement that the drug is not a cure for such disease. ${ }^{138} \mathrm{~A}$ similar proviso appears in the definition of false advertising of drugs. ${ }^{139}$ The purpose of this provision is praiseworthy and in line with the policy of the bill to place affirmative duties upon vendors and manufacturers. On the other hand, the provision seems too sweeping. If it be remembered that labeling includes at least the circulars, pamphlets, etc., enclosed within the package, the force of this provision may be that every time a disease is mentioned in any connection whatever, the cry, "this drug is no cure," must be added. So interpreted, the restriction would be onerous.

The second special proviso for drugs is as follows: the labeling (and advertising) must not include "any representation, directly or by ambiguity or inference, concerning the effect of such drug which is contrary to the general agreement of medical opinion."140 The effect of this proviso is to delete the words "and fraudulent" from the Sherley Amendment. In other words, by virtue of this section, the mere expression on a label or in an advertisement of a representation contrary to the general agreement of medical opinion becomes a violation of the federal law; courts are no longer to inquire into the mental state of the person responsible for the label or advertisement. The condition of affairs requiring the change has been discussed elsewhere. ${ }^{141}$ Making the state of opinion in the medical world determinative of falsity as to statements concerning the effects of drugs seems radical: actually, the present Act has ventured that far. For under judicial décision, the therapeutic vaticination scored by the present Act is not "false" if there exist a real difference of opinion between rival schools of medical practitioners; ${ }^{\mathbf{1 4 2}}$ aliter, if the consensus of the medical world denies its truth..$^{143}$ The contribution of the bill in this regard is that a statutory definition of falsity is provided, which, capable of explanation by regulation, should result in greater uniformity and success of administration. The interesting question is: can Congress deny movement in interstate commerce to products concerning which there have been made not false and fraudulent representations of opinion but merely false representations? The point was argued before the Supreme Court in Seven Cases of Eckman's Alterative v. United States ${ }^{144}$ where the libelee attacked the Sherley Amendment on the ground that it entered the domain of speculation and by uncertainty deprived the vendor of drugs of liberty and property in violation of the Fifth Amendment and did not permit the laying of a definite

IH Bill, $\$ 8$ (a-1). For opposition to this feature of the bill, see Drug Trade News, Sept. I8, I933, at $\mathrm{I}$; id. Oct. 2, 1933, at 33.

150 BiLI, $\$ 9(b-x)$.

${ }^{110}$ Id. $\$ 8(\mathrm{a}-2)$.

14s See supra p. 8I.

${ }^{202}$ U. S. v. Tuberclecide Co., supra note 55; Kar-Ru Chemical Co. v. U. S., 264 Fed. 921 (C. C. A. 9th, 1920); see Seven Cases, Eckman's Alterative v. U. S., supra note 29, at 517, 36 Sup. Ct. at 193.

w' U. S. v. Chichester Chemical Co., supra note 53.

is Sipra note 29. 
charge as required by the Sixth. The Court held that the objection proceeded on a misconstruction of the statute and that Congress by using the terms "false and fraudulent" had deliberately excluded the field of honest differences of opinion between practitioners. The Court, therefore, did not pass on the question whether Congress could control "false" opinion. ${ }^{145}$ There is some slight indication in the decision that the Court entertained some doubt regarding the latter. ${ }^{148}$ American School of Magnetic Healing v. McAnnulty, ${ }^{14 \tau}$ which has been urged against the Congressional power cannot be deemed authoritative, as the question answered in the negative in that case was whether the mail fraud statute ${ }^{148}$ applied to persons securing money through the mails for mental healing treatments where it was shown that such persons were honest in their belief and that a great many people believed in the efficacy of the treatment. Indeed the use interchangeably in the McAnnulty case of "false or fraudulent pretenses" and "false and fraudulent pretenses"140 without cognizance that the difference might be a constitutional law demarcation supports somewhat the validity of the suggested change. Certain language of Mr. Justice Holmes in United States $v$. Johnson ${ }^{150}$ mildly indicates the possibility of such a constitutional demarcation. Since that language was used in a decision construing the statute inapplicable to merely false opinion, his language should not be given too great force. It is important to note that the minority led by Hughes, J., specifically adverting to the question of constitutionality felt that statements prima facie of opinion became downright falsehoods of fact when contrary to general opinion and in no sense expressions of judgment beyond Congressional

${ }^{265} I d$. at 517,36 Sup. Ct. at 193 .

ss "The amendment of 1912 applies to this field [i.e. of false and fraudulent opinion] and we have no doubt of its validity." Id. at 518,36 Sup. Ct. at 193.

11787 U. S. 94,23 Sup. Ct. 33 (1902).

ses "The Postmaster General may, upon evidence satisfactory to him that any person is engaged in conducting any fraudulent lottery ... or in conducting any other scheme or device for obtaining money through the mails by means of false or fraudulent pretenses, representations, or promises instruct postmasters. ..." I7 STAT. 322 (I872), 28 STAT. 964 (1895), 39 U. S. C. A. 5259.

${ }^{20}$ See opinion of Peckham, J., in American School of Magnetic Healing v. McAnnulty, stpra note 147 at 104,23 Sup. Ct. at 37 .

${ }^{250}$ "In view of what we have said by way of simple interpretation we think it unnecessary to go into considerations of wider seope. We shall say nothing as to the limits of constitutional power, and but a word as to what Congress was likely to attempt. It was much more likely to regulate commerce in food and drugs with reference to plain matter of fact so that food and drugs should be what they professed to be, when the kind was stated, than to distort the uses of its constitutional powers to establishing criteria in regions where opinions are far apart. See School of Magnetic Healing v. MeAnnulty." Holmes, J., in U. S. v. Johnson, supra note 50, at 498,31 Sup. Ct. at 628 (italics ours).

It is difficult to escape the suspicion that behind these doubts lies some fear of invading the right of free expression protected by the First Amendment, even though no reference thereto appears in the opinions.

200 "Nor does it seem to me that any serious question arises in this case as to the power of Congress. I take it to be conceded that misbranding may cover statements as to strength, quality, and purity. But so long as the statement is not as to matters of opinion, but consists of a false representation of fact-in labeling the article as a cure when it is nothing of the sort from any point of view, but wholly worthlessthere would appear to ba no basis for a constitutional distinction. It is none the less descriptive-and falsely descriptive of the article. Why should not worthless stuff, purveyed under false labels as cures, be made contraband of interstate commerce as well as lottery tickets?" Hughes, J., in U. S. v. Johnson, supra note 50, at 506, 3 I Sup. Cr. at 63I. Harlan and Day, JJ., concurred with Hughes, J. The fact that the 
control. ${ }^{151}$ Where, in the Court's own words, a "consensus of opinion" has shown a product unquestionably harmless with respect to its contemplated uses, a state cannot completely prohibit its presence in food. ${ }^{152}$ It is difficult to see why the converse should not be true; the due process limitation should not stand in the way of legislative power striking representations contrary to that "consensus of opinion." Whether "the general agreement of medical opinion" is a sufficiently definite standard in a criminal statute is another matter.

United States $v$. Johnson has been relied upon by those who contend that in no case does the present Act reach representations of opinion. Fraudulent statements of opinion being misrepresentations of a mental state are patently representations of fact and could have been reached without the Sherley Amendment. The significance of that amendment-it is submitted-lay largely in its inclusion of opinion representations in the field of therapeutic effects of drugs which technically were not statements of identity, composition, or quality. The bill adopts language which is designed to prevent a construction limiting its prohibitions to representations of fact. In the case of advertisements, representations of opinion are explicitly included. ${ }^{153}$ In misbranding, however, the term "opinion" is not employed, thus opening the way for the construction that no extension is made to the prior law. However, the terms "ambiguity or inference" taken with the "impression" test may nullify the effect of such omission and cover anything contained on the labeling which produces a misleading impression, regardless of distinctions stemming out of the law of deceit. ${ }^{154}$ So construed, the constitutional issue regarding the power of Congress to prevent the expression of misleading opinions which are not fraudulent is squarely raised. The weak dicta in the cases which have been reviewed, especially in the light of the dissent of Mr. Justice Hughes in United States v. Johnson, do not preclude a decision sustaining these sections. The statute, it will be noted, outside the field of therapeutic effects, leaves the definition of falsity of opinion to the courts.

\section{Fatse Advertising Under the BiLl}

Reference has been made passim to the false advertising provisions of the bill. As noted, dissemination in interstate commerce of false advertisements inducing the purchase of food, drugs or cosmetics and the dissemination by any means of false advertisements inducing the sale of such articles in interstate commerce are prohibited. "False advertisement" is used as a term of legislative art. It is an advertisement which is untrue in any particular or misleading regarding the food, drug, or bill makes general medical opinion the test of the falsity other than the general point of view mentioned by Hughes, J., should not make a constitutional difference. Cf. U. S. v. Chichester Chemical Co., sutpra note 53, where the opinion of the medical world was deemed determinative of the falsity of a therapeutic representation under the Act.

${ }^{162}$ See Price v. Illinois, 238 U. S. $446,452,35$ Sup. Ct. 8 s2 (1915).

${ }^{253}$ The term advertisement includes all representations of fact or opinion disseminated in any manner or by any means other than by the labeling. BiLI, $\$ 2$ (j).

${ }^{1 s s}$ See Handler, False and Misleading Advertising (1929) 39 Y YLE L. J. 22, 32. 
cosmetic advertised. ${ }^{155}$ It is an advertisement of a drug which does not state that the drug is not a cure for a mentioned disease. ${ }^{156}$ It is an advertisement of a drug which contains representations contrary to the general agreement of medical opinion. ${ }^{157}$ Finally, "false advertisement" of a drug is one representing it directly or by ambiguity or inference to have any effect in the treatment of thirty-six named diseases, ailments, and disorders beginning with albuminuria and ending with whooping cough. ${ }^{158}$ The ground for this last prohibition is stated as the legislative declaration that Congress wishes to discourage the public advertisement for sale in interstate commerce of drugs for diseases wherein self-medication may be especially dangerous or patently contrary to the interests of public health. An exception thereto relates to advertisements disseminated to members of the medical and pharmacological professions only or as to advertisements appearing in scientific periodicals. ${ }^{160}$ There is a proviso that when medical science makes self-medication safe as to any of the "diseases" enumerated, the Secretary of Agriculture may authorize the advertisement of drugs for such disease, subject to such conditions and restrictions as he may deem necessary in the interests of the public health. ${ }^{160}$ A procedure is also provided by which the Secretary may add "diseases" to the index expurgatorius. ${ }^{101}$

If this bill passes, it will not be the first attempt on the part of the Federal Government to control advertising. An examination of the statute books reveals that such advertising is already controlled under the Aliens and Citizenship Law, ${ }^{102}$ the Lotteries Law, ${ }^{163}$ the National Prohibition Act, ${ }^{164}$ the Federal Reserve Bank Act, ${ }^{105}$ the Federal Farm Loan Act ${ }^{168}$ and the Securities Act. ${ }^{107}$ The need for controlling false advertising relating to foods, cosmetics, and especially drugs seems particularly urgent. The civil remedies for the false advertising of these articles are inadequate and serve as the slightest of deterrents. ${ }^{108}$ The Federal Trade Commission is ham-

${ }^{105}$ Binl, $\$ 9$ (a). But the falsity here must be regarding the product itself. As already noted the advertisement is false which creates misleading impressions. On the whole question of advertising and the bill, see Tugwell, Advertising and the New Food and Drugs Bill, Edror AND Publisher, Nov. 1933. For opposition to the bill's prohibition of false advertising, see Nichols, Beat the Tuguell Billl (r933) I75 Printers' INK 6.

${ }^{266}$ BILL, $\$ 9$ (b) (I). For an unduly critical analysis of this section, see (r933) 33 Druc AND Cosmertuc INDUSTRY 225.

${ }^{157}$ BILl, \$9 (b) (2).

${ }^{168}$ Id. $\$ 9$ (c). The "diseases" named are: albuminuria, appendicitis, arteriosclerosis, blood poison, bone diseases, cancer, carbuncles, cholecystitis, diabetes, diphtheria, dropsy, erysipelas, gallstones, heart diseases, high blood pressure, mastoiditis, measles, meningitis, mumps, nephritis, otitis media, paralysis, pneumonia, poliomyelitis, prostate gland disorders, pyelitis, scarlet fever, sexual impotence, sinus infections, smallpox, tuberculosis, tumors, typhoid, uremia, venereal diseases, and whooping cough.

${ }^{150} I d$.

${ }^{100}$ Id.

${ }_{102} I d$.

${ }^{100} 39$ STAT. 879 (I9I7), 8 U. S. C. A. $\$ 142$.

${ }^{253} 28$ STAT. 963 (1895), I8 U. S. C. A. $\$ 387$.

${ }^{104} 4$ I STAT. 313 (x9I9), 27 U. S. C. A. \$29, 30.

${ }_{100} 44$ STAT. 628 (1926). I2 U. S. C. A. $\$ 584$.

${ }^{20 t}$ Cf. National Securimes ACt, \$2 (I0), 5 (I).

${ }^{168}$ See Handler, supra note 154 , at 23 . As illustrative of the particular difficulties in recovering for damages through falsely advertised foods, see Alpine v. Friend Bros., Inc., 244 Mass. 164, 138 N. E. 553 (1923) ("growa folks and children alike may eat as many slices as they please without fear of harm" not a representation that specific slice did not contain a piece of tin). 
pered by the limited power granted by its organic statute, and can intervene in the interests of unfair competition, but not solely on behalf of the consumer's health. ${ }^{169}$ The Printers Ink Model Statutes ${ }^{170}$ and other state legislation on false advertising have sonorous language implying a Sinaitic force which unfortunately is lacking. Actually, these statutes are in terms usually confined to misrepresentation of fact, leaving the door open to "puffing," the advertiser's godsend.171 In practice, so far as their application is to patent medicine advertising, they are generally restricted to grossly fraudulent statements of fact and were dead letters to all intents and purposes over a decade ago. ${ }^{172}$ The postal laws have not been very helpful. ${ }^{173}$ That these statutes are ineffective is indicated by the very tide of legislation covering the advertising of specific articles. ${ }^{174}$ It is significant that most of this supplemental legislation deals with food and drug products. ${ }^{175}$

The prohibition of false advertising in channels of interstate commerce is clearly within the federal power to regulate such commerce and may be exercised unless balked by intrusion of other constitutional law objections. Whether Congress can also restrain advertising appearing in intra-state media when the advertising induces the sale of goods across state lines (as provided in the bill) is a question which will be discussed in connection with the adulteration provisions of the bill. For the present, it will be assumed that the commerce clause extends to such advertising and that the Fifth Amendment represents the sole hurdle. In an opinion breathing sentiment rather than legal citation or logic, the Supreme Court has upheld a statute making it a misdemeanor to sell, expose for sale, or possess for sale any article of merchandise upon which there was placed for purposes of advertisement a representation of the flag of the United States. ${ }^{176}$ The Court did not seem to pass on the point of the validity of the statute as applied to articles upon which the representation of the flag had been placed prior to the statute. ${ }^{177}$ The Court has held that under the police power a state may validly regulate advertising connected with the sale of tobacco ${ }^{178}$ and has sustained as valid as against the test of due process a city ordinance prohibit-

\footnotetext{
${ }^{100}$ Raladam Co. v. F. T. C., 42 F. (2d) 430 (C. C. A. 6th, I930), aff'd, 283 U. S. 643, 5I Sup. Ct. 587 (193I). On this aspect of advertising control, see Handler, Jurisdiction of Federal Trade Commission over False Advertising (I93I) 3I CoL. L. REv. 526; Note (I93I) 40 YALE L. J. 6I7; Note, supra note I02.

${ }^{170}$ For a collection of the Printers' Ink statutes, see Note (I927) 36 YALE L. J. II55.

${ }^{171}$ See Handler, supra note 154, at 32 et seq.; Note (I93I) 40 YALE L. J. 617, 621.

${ }^{172}$ See Cramp, Truth in Advertising Drug Products (I920) то AM. J. Pub. Heslth 783, 788. Expenditures for advertising by companies in the food field run into the millions. See Food FIELD REPORTER, Nov. 6, 1933, at 24. For the year 1929 , about $\$ 1,782,000,000$ was spent in advertising to the consumer. Lynd, The People as Consumers, 2 RECENT Socinl Trends (1932), 857, 87r.

27 See Handler, supra note 154 , at 30 .

dr' See Note (1930) 43 Harv. L. REv. 945.

${ }^{173}$ Id. at 947 .

${ }^{17}$ Halter v. Nebraska, 205 U. S. 34, 27 Sup. Ct. 4I9 (I907). Contra: Ruhstrat v. People, I85 Ill. I33, 57 N. E. 4 I (1900).

${ }^{2 r 7}$ Such a statute was declared invalid as to articles on which the representation had been placed before passage of the statute. People ex rel. McPike v.. Van De Carr, I78 N. Y. 425, 70 N. E. 965 (1904).

${ }^{173}$ See Packer Corp. v. Utah, 285 U. S. 105, 108, 52 Sup. Ct. 273, 274 (1932), (1932) 5 So. Carif. L. REv. 326.
} 
ing advertising trucks. ${ }^{179}$ In the state courts, ordinances prohibiting the unlicensed distribution of circulars on public highways ${ }^{180}$ and the sale of periodicals with horse racing tips have survived judicial scrutiny. ${ }^{181}$ A statute forbidding the distribution of medicinal preparations from house to house is proper. ${ }^{182}$ More closely, it has been held that a lawyer can be denied the right to advertise for business in divorce litigation even though he so advertised and was admitted to the bar before the passage of the statute ${ }^{183}$ and a number of decisions sustain statutes providing that a state board shall have the power to revoke the license of physicians and osteopaths who advertise "relating to venereal diseases or other matter of any obscene or offensive nature derogatory of good morals." 184 On the other hand, a statute revoking a physician's license for advertising which contains "grossly improbable statements" has been held too indefinite. ${ }^{185}$ A statute authorizing revocation for "causing the publication and circulation of an advertisement relative to any disease of the sexual organs" has met a similar fate on the ground that the court was given no guide as to the meaning of "any disease of the sexual organs,"186 an objection which may be obviated by the power which the present bill gives to the Secretary of Agriculture to issue explanatory regulations. ${ }^{187}$ The Congressional declaration that self-medication for the thirty-six diseases is dangerous and that such advertisements are patently contrary to the interests of public health is not binding upon the court, ${ }^{188}$ and thus will be subject to judicial review. Where the danger of self-medication is clear or where the matter is arguable, due process should not hinder the sweep of the Congressional prohibition of the false advertising. ${ }^{180}$

\section{ADULTERATTON UNDER THE ACT}

The present Act gives the consumer somewhat better protection in the field of adulteration. As used in the Act and in judicial decision, "adulteration" has two aspects, an economic and a hygienic. The first consists in the complete or partial

${ }^{170}$ Fifth Avenue Coach Co. v. New York, 221 U. S. 467, 3 I Sup. Ct. 709 (IgII). Cf. Cusacl: Co. v. Chicago, 242 U. S. 526, 37 Sup Ct. 190 (1917)

${ }^{180}$ Almassi v. City of Newark, 150 Atl. 217 (N. J. C. P. 1930), (1930) 5 TeMPLE L. Q. I50.

${ }^{181}$ Solomon v. City of Cleveland, 26 Oh. App. 19, I59 N. E. 121 (I926), cause dismissed in r16 Ohio St. 739,158 N. E. 8 (1927).

${ }^{189}$ Ayers v. State, 178 Ind. 453,99 N. E. 730 (1912).

${ }^{183}$ State v. Giantvalley, 123 Minn. 227, r43 N. W. 780 (1913).

${ }^{184}$ Glass v. Board of Medical Examiners, 50 Cal. App. 389, r95 Pac. 73 (1920); Kennedy v. State Board, I45 Mich. 24I, 108 N. W. 730 (Ig06); State Board v. Macy, 92 Wash. 6r4, 159 Pac. 801 (x9x6); Laughney v. Maybury; I45 Wash. I46, 259 Pac. I7 (I927); Note (1928) 54 A. L. R. 400.

${ }_{185}$ Hewitt v. Board of Medical Examiners, 148 Cal. 590, 84 Pac. 39 (Ig06).

${ }^{196}$ Chenoweth v. State Board, 57 Colo. 74, I4I Pac. 132 (1913). Contra: State v. Hollinshead, 77 Ore. 473 , I5I Pac. 710 (1915). But of. cases cited note 184 supra.

${ }^{187}$ Biri, $\$ 23$ (a). But see infra note 267 .

${ }^{288}$ See Block v. Hirsh, 256 U. S. I35, I55, 4 I Sup. Ct. 458, 459 (I92I); People v. Nebbia, 262 N. X. 259, I86 N. E. 694 (I933) cert. granted 54 Sup. Ct. ro4.

${ }_{250}$ See Heath \& Milligan Co. v. Worst, supra note I23, at 354, 28 Sup. Ct. II4, at II9; and the result achieved in Hebe Co. v. Shaw, stspra note 4. But see Brown, Legislation for Health and Safety (1929) 42 Harv. L. Rev. 866, 878 (queries if Congress can entirely prohibit proprietary medicines in view of Weaver v. Palmer Bros., 270 U. S. 402, 46 Sup. Ct. 320 (1926)). 
substitution of a less valuable though possibly equally wholesome article, ${ }^{190}$ the abstraction wholly or partially of any valuable constituent, the addition of some substance by mixing and packing which will affect strength or quality, ${ }^{191}$ or in mixing, coloring, powdering, coating or staining a food product in a manner whereby damage or inferiority is concealed. ${ }^{102}$ The second involves the addition of a poisonous or deleterious ingredient potentially rendering the article injurious to health, ${ }^{193}$ or the shipment of foods which are in whole or in part of a filthy, decomposed, or putrid animal or vegetable substance, ${ }^{194}$ or of a diseased animal or one that has died otherwise than by slaughter. ${ }^{195}$

Where the provisions relating to economic adulteration are concerned, no injury to the health of the consumer need be threatened.196 If, as in the case of confectionery, the Act mentions specific adulterants as talc or terra alba, their presence by mere chemical trace is enough to condemn the product. ${ }^{197}$ And since the Act specifically provides that the standards of the United States Pharmacopoeia or National Formulary shall obtain for drugs, deviation from those standards is violative unless the drug package is specially labeled to indicate the deviation. ${ }^{198}$ If a product's normal strength be diluted ${ }^{198}$ or if the housewife fail to find an ingredient ordinarily present, ${ }^{200}$ adulteration exists. Nor is a trade understanding a defense, unless shared in by the average consumer. ${ }^{201}$ Also, even if a product may commonly attain a degree of impurity in its natural state, no warrant to the designing seller is given

${ }^{200}$ Cf. Acr, $\$ 7$ (Food, I, 2, 3).

${ }^{102} \mathrm{Cf}$. the general provisions in Section 7 as to the article falling below professed standard or quality, and the subsection dealing with confectionery.

${ }^{102}$ Cf. Act, $\$ 7$ (Food, 4).

${ }^{103} \mathrm{Cf}$. Acr, $\$ 7$ (Confectionery) and $\$ 7$ (Food, 5). The latter makes certain exceptions for preservatives where directions are given for their removal prior to consumption.

${ }^{204}$ Cf. Acr, $\$ 7$ (Food, 6).

${ }^{295}$ Id.

208 U. S. v. Boeckel \& Co., 221 Fcd. 885 (C. C. A. Ist, 1915).

${ }^{107}$ U. S. v. Boeckel \& Co., supra note 196. That only a chemical trace was involved in the case appears in the lower court decision. N. J. No. 1642 (D. Mass. x9 44 ). The confectionery subsection, after enumerating terra alba, barytes, talc, and chrome yellow, adds "or other mineral substances." The doctrine of ejusdem generis has been applied to limit this last clause to minerals used to increase bulk and weight at the expense of quality. French Silver Dragée Co. v. U. S., I79 Fed. 824 (C. C. A. 2d, I9ro). Contra: U. S. v. Oriental Dragée Co., N. J. No. I76 (D. N. J. I909). But ejusdem generis does not govern the next confectionery clause, "or other ingredient deleterious or detrimental to health." U. S. v. WatsonDurand-Kasper Grocery Co., 25I Fed. 3 I0 (D. Kan. I917).

${ }^{198}$ Cf. ACr. $\$ 7$ (Drugs). It is interesting to note that several state statutes except from the permissible deviations from the U. S. P. and N. F. standards the following: opium, iodine, peppermint, camphor, ginger, ethyl nitrit. N. J. Comp. Stat. (1910) 2565; PA. Stat. (r920) \$9339; Tenn. Ann. Code (Shannon, r932) $\$ 6583$. Maine provides that deviations when made must be plainly stated "so as to be understood by the non-professional person." ME. REv. STAT. (1930) c. 4I, §I8. Several statutes insist on the standards of other pharmacopoeia (such as the English, French, German, American Homeopathic) if the drug be sold under a name not recognized in the United States Pharmacopoeia. HawaII REv. Laws (1925) c. 76, \$995; N. Y. Cons. Laws (Cahill, 1930) c. 15, §1359; Mass. Cum. Stat. (1927) c. 94, §I86; PA. Sтит. (I921) \$\$9339, 9340.

${ }^{100}$ U. S. v. Frank, I89 Fed. I95 (S. D. Ohio, I9II); U. S. v. Griebler, N. J. No. 37 (E. D. Ill. I908),

${ }^{200}$ For typical examples see Thornton, The Law of Pure Food and Drugs (1912) $\$ \$ 127$ (cream ale), 131 (apple jelly), 133 (berry preserves), 153 (custard).

${ }^{201}$ Wood Mfg. Co. v. U. S., 292 Fed. 133 (C. C. A. 8th, 1923). 
artifically to introduce that degree of debasement. ${ }^{202}$ The standards to be observed are determined by the courts in most instances; ${ }^{203}$ the rulings of the Department of Agriculture are advisory only.

Fortunately for hygienic protection, a food need not be actually harmful at the time of seizure. It is enough if it will become injurious in a reasonable time. ${ }^{204}$ No human intervention is necessary; if the food is naturally putrid or accidentally develops to be such, its shipment constitutes an offense. ${ }^{205}$ Not only foods but substances entering into the composition of more complex food products must pass the governmental test. ${ }^{208}$

On the other hand the adulteration provisions fail in several respects to protect the consumer. Difficulties begin to arise when the law seeks to reach artificially compounded food preparations and drink concoctions. ${ }^{207}$ Since no standard of sweetness is fixed, adding glucose does not adulterate. ${ }^{208}$ The addition of water in excess of the average moisture has been held not an adulteration. ${ }^{209}$ If, by the consumer's good fortune, the distinctive trade name actually mentions an ingredient, the food or drink must have it unless the defendant proves that no one expects its presence. ${ }^{210}$ But if the manufacturer adroitly avoids mentioning what product is imitated by his own, gives his product a fanciful name such as "Banquet Spread" with no reference to an ingredient, and does not sell his product for the imitated

${ }^{200}$ U. S. v. 154 Sacks, Oats, 283 Fed. 985 (W. D. Va. 1922).

${ }^{20 s}$ On the need of standards, see Rep. Sec. Agr. (rgr3) 18; id. (rgr6) 36; Chuse \& Schrink, op. cit. supra note 56, at 64, 197-217. For standards as provided in the present Act, cf. 42 STAT. 1500 (1923), $2 I$ U. S. C. A. §6; 46 StAT. rorg (1930), 2 I U. S. C. A. \$ro (5) (Supp. 1929).

${ }^{204}$ U. S. v. 462 Boxes, Oranges, 249 Fed. 505 (D. Colo. 1917); U. S. v. 200 Cases, Canned Salmon, 289 Fed. I57 (S. D. Tex. I923); Anderson \& Co. v. U. S., 284 Fed. 542 (C. C. A. 9th, 1922). The Government need not prove that the article of food because of its adulteration must affect public health; if the product may injure any group, old, young, well, sick, and in any culinary form, it is adulterated. See U. S. v. Lexington Mill \& Elevator Co., 232 U. S. 399. 4 I I, 34 Sup. Ct. 337, 340 (1914). In England, similarly, the food need not be injurious to every person. Cullen v. McNair, 24 T. L. R. 692 (1908). But see Crawford, Technical Problems in Food and Drug Law Enforcement, supra p. 37.

${ }^{205}$ Dade v. U. S., 49 App. D. C. 94 (1913); cert. denied, 229 U. S. 6ro, 33 Sup. Ct. 77r (1913) (colon bacilli in milk); Galt v. U. S., 39 App. D. C. 470 (1913) (worms in flour); U. S. v. Sprague, 208 Fed. 419 (E. D. N. Y. 1913) (diseased oysters); U. S. v. 13 Crates, Frozen Eggs, stipra note II (decomposed eggs). On departmental definitions of immaturity in certain fruits, see REG. ANN, 144, 164. An argument that the Act was invalid as excluding from interstate commerce all fish and meat as technically decomposed was ruled out as specious. Anderson \& Co. v. U. S., supra note 204, at 544.

${ }^{200}$ Royal Baking Powder Co. v. Emerson, 270 Fed. 429,434 (C. C. A. 8th, I920), app. dismissed, 260 U. S. 752, 43 Sup. Ct. 166 (1922). In making inspection for adulteration, the Government is not limited to the standards of its own bulletins and circulars, nor to tests previously known to the scientific world. U. S. v. Ioo Barrels, Vinegar, r88 Fed. $47 \mathrm{r}$ (D. Minn. I9rr); Knapp v. Callaway, 52 F. (2d) 476 (S. D. N. Y. I93r). Reg. 4 is concerned with describing the ordinary methods of analysis. For the scientific problems involved in the testing of adulteration, see Winton, ThE Microscopy op VEGETADLE Foods (19I6); Leach, Food Inspection and Ansiysis (4th ed. 1920). On tests used by the Department, see Howard, .Decomposition and Its Microscopical Detection in Some Food Products (IgII) YEAnמook, Dept. Agr. 297.

${ }^{207}$ Cf. U. S. v. Auerbach \& Sons, N. J. No. I803 (C. C. S. D. N. Y. 1912) ("Milk chocolate" may contain wheat starch); U. S. v. 150 Cases, Fruit Puddine, supra note 34.

${ }^{208}$ Washburn \& Co. v. U. S., 224 Fed. 395 (C. C. A. Ist, 1915).

${ }^{200}$ U. S. v. 800 Sacks, Barley Mixed Oats, 64 F. (2d) 678 (C. C. A. 5th, 1933).

${ }^{210}$ U. S. v. Coca Cola Co., supra note 47. 
product, in relation to what is it to be deemed inferior ?211 The compound may also most mildly suggest one of several ingredients, yet there is no adulteration though the percentage of the barely suggested ingredient becomes absurdly high. ${ }^{212}$ Moreover, in view of the "Bleached-Flour" decision, ${ }^{213}$ all kinds of technical poisons may be added to foods without legal condemnation unless the amount of the added substances is such that the food is harmful to health. ${ }^{214}$ The poison must be "added"; foodstuffs poisonous in their natural condition (and not through putrid animal or vegetable substances) may pass to the consumer unchallenged by the Act. Similarly, drugs which are harmful to health under the conditions of use as presented by the vendor are exempt unless otherwise adulterated. The highly technical question of toxicity is submitted to a court and jury with frequently bizarre results. In addition, the law does not reckon with the devastating effects of cumulative injection. Again, as with misbranding, worthless cosmetics and anti-fat cures are not reached by the adulteration provisions of the Act. ${ }^{215}$ Recently, the international coöperation afforded by the Act's restrictions as to adulterated foodstuff exports ${ }^{218}$ has been confined to its literal scope of "preparation" and "packing" to meet the foreign law, and does not protect the foreign consumer from the dumping of "naturally" filthy and decayed products. $^{217}$

\section{Adulteration UNDER THE BiLl}

The bill is designed to take advantage of the retrospective wisdom which the decades have brought since Ig06. In the field of economic adulteration, the bill retains much of the existing law. ${ }^{218}$ Instead, however, of listing several operations by which damage or inferiority is concealed, the bill lays down a denunciation of such concealment in any matter. ${ }^{218}$ The mixing and packing clause has similarly been changed so as to protect the consumer from deceptions as to bulk, ${ }^{220}$ and drugs, for the first time, are brought within the mixing and packing and substitution of constituent provisions. ${ }^{221}$

${ }^{211}$ Cf. U. S. v. One Car Load, Corno Horse \& Mule Feed, supra note 35, and the result achieved in U. S. v. Ten Cases, Bred Spred, supra note 65.

${ }^{212}$ U. S. v. One Car Load, Corno Horse \& Mule Feed, supra note 35 (semble).

${ }^{223}$ U. S. v. Lexington Mill \& Elevator Co., supra note 204.

${ }^{214}$ See Wood Mfg. Co. v. U. S., supra note 46, at 86. The famous struggle within the Department of Agriculture concerning the Bureau of Chemistry occurred over precisely this matter. Cf. WILEY, THE History of a Crime Against the Food Law (1929).

${ }^{215}$ See note 71, supra; "Lesser Slim Figure Bath" (1929) 92 Am. MEd. Assn. I. 492.

${ }^{210}$ AcT, \$2.

${ }_{217}$ U. S. v. Catz American Co., 53 F. (2d) 425 (C. C. A. 9th, I93x).

${ }^{213}$ The bill emphasizes the two types of adulteration by listing them in separate paragraphs. Cf. Birl, $\$_{3}$ (a) with $\$_{3}$ (b). In addition to the changes listed in the text, the bill makes several other changes, the most important of which is its control of coal tar. Cf. BirL, $\$_{3}$ (d). The bill does not restrict filth, putridness, and decomposition to animal and vegetable substances. Id. $\$ 3$ (a) (3).

${ }^{210} \mathrm{BIIL}, 5_{3}$ (b) (3).

${ }^{200} \mathrm{C} f$. BrLL, $\$_{3}$ (b) (4) with Act, $\$ 7$ (Food, $\mathrm{r}$ ). The language of the bill is sufficiently broad so that it will strike at false top packing.

${ }_{2 n} \mathrm{BiLL}, \S_{4}$ (d). It is diffeult to understand, however, why the bill is so considerably narrower in the field of economic adulteration of drugs than in that relating to foods. Cf. Bill, $\S_{4}$ (d) with $\$ 3$ (b). 
The chief contribution of the bill relates to hygienic adulteration. A food is to be deemed adulterated "if it is or may be dangerous to health"222 and a drug likewise shall be adulterated "if it is or may be dangerous to health under the conditions of use prescribed in the labeling thereof."223 The introduction of terminology dealing with foods and drugs potentially dangerous to health but verbalizes the present law with respect to added deleterious ingredients. ${ }^{24}$ What is important is the extension of this aspect of the present law to cover all forms of adulteration and the emphasis on the result rather than on the manner in which the adulteration has been accomplished. Whether the bill adequately strikes food products dangerous to health through their cumulative ingestion is not certain, ${ }^{225}$ though such danger is often most serious, and the provision noted is whipping in that direction. The "Bleached Flour" decision is avoided by providing that the Secretary may fix tolerances for poisonous ingredients. ${ }^{26}$ The test as to the presence of technical poisons would henceforth not depend on whether the poison is present in such proportion as actively to threaten the consumer's life. The Government would no longer permit the fruit grower to play unduly with poisonous sprays but would establish a border zone, trespass beyond which would bring the federal penalties. Food is also to be adulterated if packed in containers composed of poisonous or deleterious substances which may by contamination render the contents dangerous to health.227 Drugs must more closely conform to the United States Pharmacopoeia or National Formulary, ${ }^{228}$ although deviation is still permitted if noted on the label. Cosmetics are

${ }^{2} I d . \S_{3}(\mathrm{a})(\mathrm{x})$. The language is designed to hit the foods containing "natural" poisons.

${ }^{223} I d . \$ 4$ (a).

See note 204, supra.

$22 \pi$ The cumulative ingestion problem seems noted only in the section dealing with tolerances of added poisons. BILI, \$ro (a). Moreover, the very expression of the cumulative test in this section will tend to negate its application in the other types of adulteration.

${ }^{20} \mathrm{Id}$. The bill omits completely the Act's permission of such ingredients for preservatives, a permission given only if directions for removal are given. Cf. Acr, 87 (Food, 5). In absence of a statutory exception, a substance is an adulterant though its purpose and use are preservative. Pcople v. Bowcn, I82 N. Y. I, 74 N. E. 489 (1905); Commonwealth v. Gordon, 159 Mass. 8, 33 N. E. 709 (1893); State v. Schlenker, II Iowa 642,84 N. W. 698 (1900).

${ }_{227} I d$. $\$_{3}$ (a) (6). There is no analogous provision for drugs. The test given by the Bill contrasts with its general emphasis on result rather than on method of adulteration; in this instance of the container the Bill regards the composition of the container too closely and docs not strike at adulteration gained through interaction with containers howsoevcr occasioned. Cf. the somewhat broader language of state statutes dealing with this question. VA. Code (Michie, 1930) \$II8I (7). KEN. REv. STAT. (Carroll, 1930) \$2060a-2 makes food misbranded if the label fails to disclose the length of time of packing where retention unduly prolonged would tend to render the food unwholesome.

${ }_{223}$ BinL, $\$ 4$ (b). The bill recognizes the supplements official at the time the drug is introduced into interstate commerce. Under the Act the standard of these volumes became operative when the drug was "sold" under the names recognized in the Pharmacopoeia and Formulary. Acr, \$7 (Drugs, 1). Under the Bill, the drug's name need only be the same or simulative of the name of drugs in those volumes. Under the Act, the drug had to meet the U. S. P. or N. F. standards of strength, quality, and purity. The bill adds that the drug must meet the U. S. P. or N. F. "definition, formula and description." The drug must meet the standards of the U. S. P. or N. F. in accord with the tests or methods of assay given in these volumes, or those of the Secretary if he finds the former insufficient. Note that this docs not give the Secretary power to fix drug standards; he is merely given power to prescribe tests for the determination of the U. S. P. or N. F. standard. Cf. a similar power given to the Canadian Governor in Council. Can. Rev. Stat. (I917) c. $76, \$ 6$ (4). But the Canadian Governor may prescribe drug standards 
deemed adulterated if presently or potentially injurious to the user under the conditions prescribed in the labeling or under such conditions of use as are customary. ${ }^{229}$ In addition, cosmetics must not bear or contain poisonous or deleterious ingredients prohibited, or in excess of the limits of tolerance to be established. ${ }^{230}$ Instead of the prior detailed provision as to what confectionery might not contain, the present confectionery clause reads simply that confectionery may not bear or contain any alcohol, resinous glaze, or non-nutritive substance. ${ }^{231}$ The revision seems primarily directed at the metallic tokens and prizes which are too often packed inside candy boxes or placed even within the candy itself. ${ }^{232}$

But included in Section 3 of the bill, a section dealing with the adulteration of foods, is a clause which though innocent at first reading represents, with the exception of the National Recovery Act and attendant legislation, one of the most powerful thrusts of the federal power into what has hitherto been a realm of affairs solely the province of the states and which has been considered in the main immune from federal intervention. Section 3(a) (4) provides that a food is to be deemed adulterated "if it has been prepared, packed, or held under unsanitary conditions whereby it may have become contaminated with filth." ${ }^{233}$ This is plainly an indirect method of controlling the conditions of packing and manufacture. The bill is not satisfied with this indirect control. Under the present Act, the Department's lack of power to inspect places where food is prepared has hindered its reaching certain types of adulteration which elude chemical and bacteriological tests. ${ }^{234}$ Section I2 (which if read closely will be found to deal only with this situation) provides that in such cases, the Secretary of Agriculture after notice and hearing may make such regulations governing the conditions of manufacture, processing, or packing as he deems necessary to protect the public health, and may require the manufacturers, processors, and packers of such classes of articles to hold a permit conditioned on compliance with such regulations. The section applies to drugs and cosmetics as well as foods,

in addition to tests. Id. $\$ 6(3)$. On the constitutionality of prescribing the method of determining a standard, see L. R. A. I916 E379. In Savage v. Jones, supra note 4, the Indiana statute before the Court provided that constituents were to be determined by the methods recommended by the Association of Official Agricultural Chemists of the United States. The question of its constitutionality on this score was not considered.

$2 \approx 0$ BiLl, \$5 (a).

${ }^{200} \mathrm{Id}$. $\S_{5}(\mathrm{~b})$.

${ }^{237}$ Id. $\$_{3}(c)$. Coloring and flavoring are expressly cxcepted and may be present though non-nutritive. In the following state statutes, substances permitted by the federal law are prohibited in confectionery: AlA. ANn. CODE (Michie, 1928) $\$ 4402$ (burnt umber); IrL. REv. Stit. (Cahill, I929) c. 56 b, $\$ 8$ (paraffin); Neb. CoNpp. Stat. (I929) \$8I-903 (paraffin); N. D. CoMp. LAws (1913) \$2280 (aniline dyes); UTAH CoMp. LAWs (I9I7) \$1927 (2) (paraffine). Maryland specifically permits "salt" in confectionery. MD. ANN. CODE (Bagby, I924) art. 43, \$I9r.

272 Cf. Neb. Comp. Stat. (1929) \$81-g03.

${ }^{233}$ The bill as phrased does not seem to include unsanitary conditions of transportation. Those state food and drug laws which have advanced to control the surrounding conditions are couched in more sweeping language. Cf. Me. Rev. Stat. (I930) c. 4r, \$18 (7); Pa. Stat. (I920) §6r; N. Y. Cons. Laws (Cahill, 1930) c. I, \$199 (8); TEx. PEN. CODE (1928) art. 707. For the validity of an analogous provision, see People v. Bowen, I82 N. Y. I, 74 N. E. 489 (I905).

${ }^{24}$ See Crawford, supra p. 38. 
and the introduction into interstate commerce of any food, drug, or cosmetic is forbidden if the manufacturer, processor, or packer does not hold a valid and subsisting permit when so required. Further, in order to aid in enforcement, officers or employees designated by the Secretary, after first obtaining permission of the owner, operator, or custodian thereof are authorized to enter and inspect any factory, warehouse, or establishment in which food, drugs, or cosmetics, are manufactured, processed or held for shipment in interstate commerce or are held after the interstate shipment. ${ }^{235}$ The permission required of the owner, operator and custodian is illusory; if they do not grant the permission, an injunction may issue denying articles coming from such factories, warehouses, vehicles, etc., the right to enter into the interstate commerce or to be delivered after their receipt in interstate commerce. ${ }^{230}$

These provisions abut very closely upon the theoretical line separating state and federal powers. While not as far-reaching as the recent emergency legislation enacted by Congress, they raise similar questions. Formulae to sustain this extension of control are not lacking. ${ }^{237}$ It must be remembered that the measures taken are designed merely to protect the stream of interstate commerce. No jurisdiction is assumed over articles which do not at some time cross state lines. The difficulties of the Child Labor decision ${ }^{238}$ are only apparent; the Court itself in that decision distinguished its food and drug law precedents by the dictum that the goods made by child labor were in themselves harmless. ${ }^{239}$ Moreover, the Court has nominated adulterated foods and drugs "illicit articles" and has expressly refused to apply to them the rule marking the line between the exercise of federal and state power over articles of "legitimate commerce." 240 If Congress can provide for the inspection of

\footnotetext{
${ }^{225}$ BrLI, $\$ \mathrm{r}_{3}$ (a). Similar powers have been granted the Department in analogous statutes. Cf. Meat Inspection Law, 34 STat. 1260, 1262 (1907), 21 U. S. C. A. \$\$7r, 76; Biologic Products Law, 37 STAr. 833 (r913), 21 U. S. C. A. \$157; Import Milk Act, 44 STAт. Iror, Iro2 (1927), 21 U. S. C. A. \$143; Adulterated Butter Act, 32 STAT. 196 (r902), 26 U. S. C. A. $\$ 578$. The bill's provision docs not appear to violate the provisions of the Fourth and Fifth Amendments. See cases collected in (I93I) I5 MrNN. I. REv. 48I; (I93I) 25 III. L. Rev. 937. But cf. U. S. v. Mulligan, 268 Fed. 893 (N. D. N. Y. 1920); Sullivan v. Brawner, $237 \mathrm{Ky} .730,36 \mathrm{~S}$. W. (2d) 364, (193I). The requirement of an ordinance that samples be given food inspectors without compensation has been held a valid exercise of police power. State v. Dupaquier, 46 LA. ANN. 577, $x_{5}$ So. 502 (I894); St. Louis v. Liessing, I90 Mo. 464,89 S. W. 6II (1905); Com'r v. Carter, I32 Mass. 12 (1882). Possibly, even in absence of statutory authority, the taking of the sample without payment therefor comes within the rule of de minimis. Cf. U. S. v. B. \& M. External-Remedy, 36 F. (2d) 53 (S. D. N. Y. r929). Several of the state food and drug laws have more sweeping inspection provisions than that of the bill. Idaнo, Comp. Stat (1919) 51675; ILI. Rev. Stat. (I929) c. 56 b, \$2; Kans. Rev. Stat. (I923) \$65-612; Minn. Stat. (I927) \$3798.

$200 \mathrm{BrI}, 5 \mathrm{I}_{3}$ (b).

${ }^{20}$ See Dickinson, Major Issues Presented by the NIRA (1933) 33 Cor. L. REv. 1095, I099, and the discussion of the commerce clause in Handler, The National Industrial Recovery Act (1933) I9, AM. B. AssN. J. 440. In Canada, the Governor in Council may license manufacturers preparing a list of named drugs. Can. Rev. Stat. (1927) c. 76, 56 (3-c).

${ }_{23}$ Hammer v. Dagenhart, 247 U. S. 25I, 38 Sup. Ct. 529 (1918).

${ }^{230}$ Id. at 270-272, 38 Sup. Ct. at 530-53r.

${ }^{210}$ Hipolite Egg: Case, supra note 8, at 57, 31 Sup. Ct. at 367 . For an analysis of 'this doctrine of "illicit" articles, see Corwin, Congress's Power to Prohibit Commerce (r933) 18 ConN. L. Q., 477, 479.
} 
such goods after they have come to rest and have been commingled with local products, ${ }^{241}$ it may with equal propriety cause the goods to be inspected before their start on the interstate journey ${ }^{242}$-at least in those cases when such inspection possesses sole efficacy.

The bill's advertising control suggests similar constitutional questions but is easier to sustain because limited to transmission of intelligence across state lines and the solicitation of interstate sales. ${ }^{243}$ Weeks $v$. United States ${ }^{244}$ held that Congress could prevent the interstate shipment of foods orally offered under the name of other foods. The converse corollary that Congress may control the representations concerning goods moving in the stream seems evident. The power of Congress should not depend on the mere location of the statement affecting the article. ${ }^{245}$

\section{Regulatrons Under the Act and Bill}

No review of the substantive provisions of the bill would be complete without attention to the wide powers which it gives to the Secretary of Agriculture. Under the present Act the power to make rules and regulations for the carrying out of the provisions of the Act is lodged in a triumvirate consisting of the Secretaries of the Treasury, Agriculture, and Commerce. ${ }^{246}$ The Act contents itself with this general delegation of power; with the exception of the tolerances and exemptions as to small packages under the Gould Amendment, ${ }^{247}$ it fails to establish any directive standards for the exercise of the power. The bill contrasts. It is replete with reference to the executive power which, with the exception of import regulations shared with the Secretary of the Treasury, ${ }^{248}$ is vested solely in the Secretary of Agricul-

\footnotetext{
211 Hipolite Egg Case, supra note 8; see McDermott v. Wisconsin, supra note 4, at 135, 33 Sup. Ct. at 436 ("Congress may determine for itself the character of the means necessary to make its purpose effectual in preventing the shipment in interstate commerce of articles of a harmful character, and to this end may provide the means of inspection, examination and seizure necessary to enforce the prohibitions of the act. . . . The opportunity for inspection en route may be very inadequate."); Foote v. Maryland, 232 U. S. 494,34 Sup. Ct. 337 (1914).

${ }^{202}$ See the conclusion drawn by Holmes, J., from the Hipolite Egg Case and Weeks v. United States: "It does not matter whether the supposed evil precedes or follows the transportation. It is enough that in the opinion of Congress the transportation encourages the end." This was expressed in his dissenting opinion, Hammer v. Dagenhart, supra note 238 , at 279,38 Sup. Ct. at 534, but as indicated in the text, the distinction there taken by the majority is inapplicable to foods packed under unsanitary conditions or conditions making detection of adulteration difficult. In Pittsburgh Melting Co. v. Totten, 248 U. S. I, 8 , 39 Sup. Ct. 3, 4, (1918) the court said of the Meat Inspection Statute "The enactment of the statute was within the power of Congress in order to prevent interstate and foreign shipment of impure or adulterated meat-food products." Cf. also U. S. v. Cudahy Packing Co., 243 Fed. 44I (D. Conn. I917). The Meat Inspection statute was apparently unchallenged in Brougham v. Blanton Mfg. Co., 249 U. S. 495, 39 Sup. Ct. 363 (r919).

${ }^{23}$ Such solicitation is part of interstate commerce. See Robbins v. Shelby Taxing District, I20 U. S. 489, 497, 7 Sup. Ct. 592, 596 (I887); Crenshaw v. Arkansas, 227 U. S. 389, 396, 33 Sup. Ct. 294 (I913); Note (1927) 48 A. L. R. 563 .

34 Supra note 5.

${ }^{24}$ See Seven Cases, Eckman's Alterative v. U. S., supra note 29, at 515, 36 Sup. Ct. at I92.

its Acr, \$3.

2r Supra note 26.

${ }^{23} \mathrm{Cf}$. Section 23 (a) of the bill with the subject matter of Section 20.
} 
ture. ${ }^{249}$ Under the bill, he has power, inter alia, to make regulations as to coal-tars and certify batches of coal-tars; ${ }^{250}$ to adopt tests and methods of assay whenever he finds those of the United States Pharmacopoeia or National Formulary insufficient, ${ }^{251}$ to prescribe the manner and form of statements on drugs which deviate from the standards set in those volumes; ${ }^{262}$ to fix, establish, and promulgate definitions of identity and standards of quality and fill of container for any food; ${ }^{263}$ to prohibit added poisons or establish tolerances for such poisons; ${ }^{254}$ to regulate factories manufacturing classes of foods, drugs, and cosmetics injurious and difficult of detection by analysis of the product itself;; $; 55$ to exempt classes of canned goods when being transported to an establishment for labeling; $;^{260}$ to require a statement of standard of quality on the label; $; 25$ to fix the statement of the quantity and proportion of hypnotic substances, alcohols, and chloroform; ${ }^{258}$ to exempt certain drugs from label requirement as to statement of condition of use; ${ }^{250}$ to authorize advertisements for self-medication ${ }^{280}$ and to add new diseases to the self-medication list. ${ }^{201}$ In the cases of foods for which no definition of identity has been provided and of drugs not mentioned in or simulative in name to those in the United States Pharmacopoeia and National Formulary, he has virtually a carte blanche respecting statements on the label. ${ }^{262}$ The promulgation of only some of these regulations must be preceded by a notice and hearing. Of these, the most important are those regulations establishing definitions of identity, standards of quality, and fill of container for any food. Here the necessity for the prior notice and hearing may become factually most burdensome and unduly delay the enforcement of the law. The notice and hearing do not appear to be required because of considerations of constitutional law; the Constitution merely demands that the regulation of the administrative officer shall not be arbitrary and would hardly seem to insist on the formal hearings which the bill so frequently contemplates. ${ }^{203}$

The delegation of the standard making and other powers to the Secretary seems well within constitutional bounds. The distributing clause is not part of the Federal Constitution, ${ }^{264}$ and in theory, so long as Congress indicates a "primary" standard, the Secretary merely fills in the details. ${ }^{265}$ Actually, the "primary" standard need

250 Id. $\$ 23(\mathrm{a})$.

${ }^{250}$ Id. \$IO (b). Cf. Id. 3 (d).

${ }^{201}$ Id. $\$ 4$ (b). See supra note 228.

252 Id.

${ }^{253}$ Id. $\$ 11$.

${ }^{204}$ Id. \$10 (a).

${ }^{255} I d . \$ 12$ (a).

$\left.{ }^{250} I d . \$ 6 \mathrm{~b}\right)$.

${ }^{35 \pi}$ Id. $\$ 7$ (e).

${ }^{258} 1 d . \$ 8$ (b) (c).

${ }^{200}$ Buttfield v. Stranahan, 192 U. S. 470 (I904); cf. Norwegian Nitrogen Products Co. v. U. S., 288 U. S. 294, 53 Sup. Ct. 350 (r933); Bi-Metallic Investment Co. v. Colorado Board, 239 U. S. 441, 36 Sup. Ct. I4I. The rule seems to be that an administrative order which, as distinguished from an administrative regulation, operates by way of individual discrimination need not be preceded by notice and hearing. Sce Note (r93I) 80 U. OF PA. L. Rev. 96.

see Note (1922) 35 HARv. L. Rev. 450, 452; Powell, Separation of Powers: Administratite Exercise of Legislative and Judicial Power (1912) 27 PoL. Sc. Q. 9, 215, 216-217.

$x^{2}$ See Note, supra note 264 . 
only be the enunciation of broad policies. ${ }^{266}$ The regulations which the Secretary makes cannot add to the law, ${ }^{267}$ and there is some indication that the definitions of identity and standards of quality and fill must be also sufficiently comprehensive as to permit the sale of all the usual classes of products without unnecessary interference. ${ }^{268}$

\section{SANCTIONS Under THE Act}

The present Act gives the Government two chief weapons, criminal prosecution of the violator under Section two and forfeiture of the outlawed goods under Section ten. The violation of the Act is a federal misdemeanor. A first offense carries a fine not exceeding two hundred dollars, and conviction for each subsequent offense not exceeding three hundred dollars, or imprisonment, not exceeding one year, or both in the discretion of the court. ${ }^{269}$ A defendant who ships several kinds of articles in one shipment can be separately fined for each, ${ }^{270}$ but cannot be subjected to a multiple rine if the shipment consists of units of the same article, though in separate packages. ${ }^{271}$ For the criminal violation no mens rea is needed except in cases involving "false and fraudulent" therapeutic claims. The Act has substituted for the common law principle of "caveat emptor" the stern principle of "caveat venditor," so that the receiving seller or shipper violates the law the moment he contaminates the stream of interstate commerce and his intentions, his care, his inspection, his knowledge or lack of knowledge of the fraud or adulteration are all immaterial ${ }^{272}$ save in the solitary instance of statements concerning the therapeutic value of drugs. The exact methods for investigation, conviction and forfeiture are detailed and fairly complex. ${ }^{273}$ The amazingly high number of pleas of guilty ${ }^{274}$ and the frequent

sou See Note (1933) 3I Micr. L. Rev. 786; Note (1929) 27 Micr. L. Rev. 558; Note (r93I) I9 CALIF. L. REv. 448.

${ }^{200}$ Lynch v. Tilden Co., 265 U. S. 315, 44 Sup. Ct. 488 (1924) (Regulation could not add "moisture" standard for adulterated butter); Waite v. Macy, 246 U. S. 606, 38 Sup. Ct. 395 (1918) (regulation cannot exclude tea having infinitesimal amount of innocuous coloring matter); see U. S. v. Antikamnia Co., supra. note 25, at 666, 34 Sup. Ct. at 225; Hayes \& Ruff, supiza p. 20, n. 20. The Secretary's finding of fact is conclusive if fairly arrived at and if it have substantial evidence in support. Houston v. St. Louis Independent Packing Co., 249 U. S. 479, 39 Sup. Ct. 332 (1919). A violation of a food regulation is sufficient to support a criminal action. United States v. Grimaud, 220 U. S. 506, 3I Sup. Ct. 480 (IgII). As to its sufficiency in a libel for seizure, cf. U. S. v. Antikamnia Chemical Co., supra.

${ }^{200}$ See the doctrines announced in Burns Baking Co. v. Bryan, 264 U. S. 504, 44 Sup. Ct. 412 (1924); Quaker Baking Co. v. Herring, 3 F. Supp. II8 (S. D. I2. I933); Holsum Baking Co. v. Green, 45 F. (2d) 238 (N. D. Ohio I930); Morgan v. Nolan, 3 F. Supp. I 43 (S. D. Ind. r933); In re Mefferd, Iro Cal. App. I, 292 Pac. 988 (1930); Marshall v. Dept. of Agriculture, 44 Idaho 440, 258 Pac. 17 (1927); Atlantic Refining Co. v. Trumbull, 43 F. (2d) I54 (D. Conn. I930), Note (1930) 40 Yale L. J. II6. But $c f$. Waters-Pierce Oil Co. v. Deselms, 212 U. S. 159, 29 Sup. Ct. 270 (1909).

200 ACT, \$2.

200 U. S. v. Direct Sales Co., 252 Fed. 882 (W. D. N. Y. I918).

${ }^{27}$ U. S. v. Watson-Durand-Kaspar Grocery Co., supra note 297; see Andersen \& Co. v. U. S., supra note 204, at 544 .

$2=$ U. S. v. 36 Bottles, London Dry Gin, supra note 45; U. S. v. 267 Boxes, Macaroni, supra note.44; U. S. v. Sprague, 208 Fed. 4 I9 (E. D. N. Y. 1913).

${ }^{2 r}$ See Hayes \& Ruff, supra p. 25 et seq.

Int The following chart was prepared by abstracting and then consolidating data from the schedules of business in the District and Circuit Courts in the annual reports of the Attorneys-General of the United States. The period covered is from the passage of the Act in 1906 through June 30, 1932. 
summoning of the same offender before the courts indicates that many firms, immune as corporations from imprisonment, ${ }^{275}$ regard the system of confiscation, suspension of sentence, and light fines ${ }^{276}$ as a very moderate license charge for plying their trade. Goods released under bond have a way of surreptitiously reaching food and drug markets, ${ }^{277}$ and by a continued series of changes in a label or formula, defendants avoid the effect of even successful prosecution.

The law has also received the support of indirect sanctions. Executory agreements under which adulterated foods move in interstate commerce may be breached with impunity, ${ }^{278}$ and violation of the statute set up as a defense to actions brought for the purchase price of retained goods. ${ }^{279}$ Where the consumer is injured because of his reliance on statements made on the label or package circulars, the violation of the Act takes the question of negligence away from the jury, ${ }^{280}$ but it has been held

Civil Forfeiture $(\$ \mathrm{I0})$

Actions commenced ..............

Judgments for U. S. . ...........

Judgments against U. S. ..........

Dismissed or discontinued after pay-

ment or compromise .............

Dismissed for other reasons........ $\quad$ I,3 16

Amount of judgment for U. S......\$197,483.60

Amount realized on such judgments

(including interest) .........\$200,772.69

Actions unaccounted for ......... I2

Actions pending June 30, 1932..... $\quad 284$

- Prior to rgrr, 83 dismissals were reported without mention of reasons. These have not been included above.

${ }^{275}$ As far as the records indicate, in the whole history of enforcement of the Act, but two prison sentences have been imposed. One was remitted, and in the other (N. J. No. 9008) a poor forcigner was sentenced to a year in jail. Prison sentences are occasionally imposed in connection with the postal, prohibition, and customs violations which are incidentally disclosed. See note 56 , supra. For successful use of an indictment for conspiracy to violate the statute, see Mitchell v. U. S., 229 Fed. 357 (C. C. A. 2d, 1916). The bill attempts to reach the corporate officers. BilI, \$18. Cf. N. Y. LAws 1909, c. 49 art. II, as amended.

${ }^{776}$ See supra p. 109.

m See (1930) II7 On, Pannt and Drug Rep. aI7; Rusby, The Fight for Pure Drugs (1930) 7 Plain TALK 333. In the years 1919 to 1922 , of $4,7 r_{3}$ decrees of condemnation 1,202 were released under bond. REP. ATt'y GeN. (I919) 84; id. (1920) r45; id. (1921) ro6; id. (1922) 87.

${ }^{27}$ Trafton v. Davis, r 10 Me. 318, 86 Atl. I79 (I913); Hopkins \& Co. v. Silverman, 234 App. Div. 224, 254 N. Y. Supp. 724 (I932) (despite technical release by Government); cf. Barron County etc. Co. v. Niana Pure Food Co., rgí Wis. 635, $21 x$ N. W. 764 (I927). But of. McNeil \& Higgins Co. v. Martin, I60 La. 443, 107 So. 299 (I926). North Dakota's food and drug law specifically provides that no action may be maintained on account of any sale or other contract made in violation of the food and drug law. N. D. Comp. Laws ANN. (Supp. 1925) \$2889a 15. In England, contracts are not generally affected by the Sale of Food and Drug Law. Cf. I8 \& 19 Geo. V, c. 3I, \$33. See also on the private right of action for violation of a commodity standards law, Note (193I) 3I CoL. L. REv. 872, 880.

${ }^{270}$ Digestive Ferments Co. v. Am. Chem. Laboratories, 80 Pa. Super. Ct. 373 (Ig23). The defense is not available where a defendant retains goods after being ordered to return them for relabeling. Makris v. Moore, $74 \mathrm{Utah}$ 478, 280 Pac. $72 \mathrm{I}$ (I929). And cf. Walker v. Gateway Milling Co., supra note 38; Hall-Baker Grain Co. v. U. S., supra note 3I. Several state food and drug laws have made the defense available as a statutory right. Mins. Stat. (Mason, I927) \$380r; N. H. PuB. Laws (1926) c. 139, \$11; ORE. CODE ANN. (r930) \$4I-225.

3 Armour v. Wanamaker, 202 Fed. 423 (C. C. A. 3d, 19r3). 
that the shipping of a "naturally" adulterated product does not have similar force. ${ }^{281}$ In accord with the general doctrine of "unclean hands," labels not meeting the requirements of the statute are not protected in suits for infringement of trade-mark, ${ }^{282}$ nor can a violator recover under the Sherman Anti-Trust Act. ${ }^{283}$ The Post Office and prohibition enforcement authorities have sometimes been able to give supplementary aid. ${ }^{284}$ Reference has already been made to the power of the Federal Trade Commission to intervene where the violation crosses into the realm of "unfair competition."285

Entrapment is a defense to prosecutions under the Act. ${ }^{288}$ The possession by a dealer of a valid guaranty, signed by a wholesaler, jobber, or other person residing in the United States, to the effect that the articles purchased are not adulterated or misbranded under the Act, is a defense, but the guarantor is liable for the penalties that would otherwise would attach to the dealer. ${ }^{287}$

\section{SANCTTONS UNDER THE BIII}

The bill strengthens the provision as to seizure and criminal penalties and adds the following weapons to the Government's arsenal: injunction, publicity, voluntary inspection system, and a right of private action. To the present method of seizure pursuant to a libel, the bill provides for an executive seizure by an order of a chief of station or other officer of the Food and Drug Administration founded on probable

${ }^{201}$ Armour \& Co. v. Miller, 39 Ga. App. 228, 147 S. E. I84 (1929), Note (1930) ๆ N. Y. U. L. Q. 738, 742. A proper label and guaranty under the Act will aid a defendant in an action brought for negligence. Cf. Bigelow v. Maine Cent. R. Co., I10 Me. I05, 85 Atl. 396 (Igr2); People v. Lang, I64 N. Y. Sup. 5 ( $(\mathrm{I} I 7)$. On the difficulties facing the plaintiff in actions brought for injury due to service of improper food, sec Perkins, Unwholesome Food (I9I9) 5 Iows L. Bul.. II, 86, 96; Shoemaker, Sales of Food by Restaurant Keeper (1927) I2 CoRN. L. Q. 535; (I927) 75 U. oF PA. L. REv. 676; (I928) 26 MICH. L. REv. 825.

Cf. American Thermos Bottle Co. v. W. T. Grant Co., 282 Fed. 426 (C. C. A. Ist, I922); See Handler, supra note 154, at 50, n. 79; HopkINs, TrADE-MARks (4th ed. 1924) \$38; Rogers, op. cit. supra note 66 , at 123. A wholly technical violation of the Act will not estop the plaintiff. Bonnie \& Co. v. Bonnie Bros., $160 \mathrm{Ky} .487$, I69 S. W. 871 (1914). Apparent departmental sanction of the plaintiff's trade-mark through lack of prosecution will aid in an action to prevent registration of an infringing trademark. See Orange Crush Co. v. California Crushed Fruit Co., 297 Fed. 892, 894 (App. D. C. I924). The Patent Office will refuse to register marks violating the Act. Ex parte Barclay \& Barclay, 135 O. G. Pat. Off. 217 (Ig08); of. Levy \& Co. v. Uri, 3 I App. D. C. 441 (Ig08).

${ }_{23}$ Proper v. Bene \& Sons, 299 Fed. 863 (E. D. N. Y. I924); see Note (I932) 32 CoL. I. REv. 335.

24 See Rep. Sec. AGr. (I914) 167; Alsberg, supra note 56, at 213. But of. Handler, supra note 154, at 32 .

${ }_{233}$ Supra note 102.

${ }^{200}$ Where the initial shipment is procured by entrapment, an indictment will be dismissed in absence of evidence of other interstate shipments. U. S. v. Eman Mfg. Co., 27x Fed. 353 (D. Colo. x920). But c. U. S. v. 50 Barrels, Whiskey, 165 Fed. 966 (D. Md. 1908).

207 AcT, \$9. See Reg. 6. The guaranty defense is available only when relating to the identical article shipped and not when concerning only a constituent used in the manufacture of the article shipped. See U. S. v. Mayfield, I77 Fed. 765,768 (N. D. Ala. I910). It may be a "continuing" guaranty. Glaser, Kohn \& Co. v. U. S., 224. Fed. 84 (C. C. A. 7th, I9I5); see Reg. 6 (d). Contra: U. S. v. Scully Syrup Co., N. J. No. 247I (N. D. Ill. I913). But a guaranty given after prosecution has been instituted, though before conviction, brings no immunity. Steinhardt Bros. \& Co. v. U. S., I9I Fed, 798 (C. C. A. 2d, IgIr). The guaranty will probably protect a dealer from prosecutions arising out of his own subguaranty. 26 Op. ATT'y GEN. (1908) 449. On the protection accorded a dealer under a state law because of a federal guaranty, see City of St. Louis v. Wortman, 213 Mo. I3I, I46, II2 S. W. 520,525 (I908). 
cause to believe that the article to be seized is so adulterated as to be imminently dangerous to health. ${ }^{288}$ This summary method of seizure does not apply at all to misbranded articles or to articles which have been economically adulterated. Its sole concern is to protect the public from foods, drugs, and cosmetics immediately dangerous to health. As such, the executive seizure seems to rest on a sound constitutional basis, ${ }^{289}$ especially since a right of action is not denied against the officer who seizes articles in fact not so imminently dangerous. Indeed, the bill makes express provision that the amount recovered in such actions shall be provided for and paid out of appropriations for the administration of the law. ${ }^{200}$ Release under bond after condemnation subsequent to the seizure becomes more clearly discretionary, ${ }^{201}$ but the destruction of articles condemned because of failure of the manufacturer, processor, or packer to hold a valid permit if same be required of them, is not discretionary but mandatory. ${ }^{292}$ The bill provides that the articles may be released for bringing into compliance with the law only if the compliance is effected under the supervision of an officer or employee designated by the Secretary of Agriculture and the expenses of the supervision paid by the party obtaining release of the article under bond.283

The criminal penalties are raised. A violation will now carry for the first offense a minimum fine of $\$ 100$, a maximum fine of $\$ x, 000.294$ A first offense will also subject the violator to imprisonment for not more than one year as alternative or in addition to the fine. A second or subsequent offense will carry imprisonment for not more than two years, or a fine of not less than $\$ 500$ nor more than $\$ 3,000$, or both such imprisonment and fine. Although as indicated the bill removes even the present sole exception requiring mens rea, the bill's penalty section takes cognizance of the distinction between wilful and non-wilful violation of the law. Under the provisions of Section $\mathrm{I}_{7}(\mathrm{c})$, in the case of wilful offense, the penalty is to be imprisonment for not less than six months nor more than three years, or a fine of not less than $\$ 1,000$ nor more than $\$ 10,000$, or both such imprisonment and fine. It is important to note that the bill thus provides for not inconsiderable minimum fines and in the case of wilful offender for the alternative of a minimum prison term of six months. Although constitutional, ${ }^{295}$ these penalties are severe, and where the

${ }^{258}$ BrLL, $\$ 16$ (a). Cf. the very drastic seizure and forfeiture provisions of Olcomargarine Act, 24 SraT. 212 (1886), 26 U. S. C. A. \$555; CAN. REv. Stat. (1927) c. 76, \$30.

${ }^{250}$ North American Storage Co. v. Chicago, 2xI U. S. 306, 29 Sup. Ct. ror (I908) (no notice or hearing needed under Fourteenth Amendment prior to seizure).

200 BIL.L, \$I6 (b).

${ }^{202} I d . \$ 16$ (d).

${ }_{2 x}$ Id. The discrimination seems justified in view of the character of the articles manufactured in such permit factories.

${ }^{203} I d$.

BIII, \$I7 (b).

${ }^{205}$ People v. Adams, I76 N. Y. 35r, 68 N. E. 636 (I903), aff'd, r92 U. S. 585, 24 Sup. Ct. 372 (I904) (the point was not argued in the Supreme Court). The question of validity which has been raised is that of constitutional provisions forbidding unusual and crucl punishments. The maximum and minimum sentence is not uncommon in statutes providing for indeterminate sentences. See Note (1928) $18 \mathrm{~J}$. Cris. 
offense is not wilful the severity may tend to lead either to acquittal or to a suspension of sentence. That the statutory crime carries prison sentences despite the absence of mens rea, is not unusual in the rapidly expanding field of "public welfare" offenses. ${ }^{206}$ A recent historical survey indicates that in the field of food control the whole doctrine of crimes without mens rea arose and cross-pollinated. ${ }^{287}$

Section Ig of the bill declares both the repetitious introduction of adulterated or misbranded food, drugs, and cosmetics into interstate commerce and the repetitious dissemination of false advertising regarding such products to be public nuisances which may be enjoined at the suit of the government. To bring the injunctive restraint within the recognized heads of equity jurisdiction of the federal courts, the statute in addition to thus utilizing the nuisance formula expressly states that the purpose of the injunctive power is to avoid multiplicity of criminal proceedings.

Statutory analogies for an injunction sanction in a criminal statute are not lacking. The Sherman Law, ${ }^{298}$ the Prohibition Law, ${ }^{299}$ the National Industrial Recovery Act, ${ }^{300}$ and the new Securities $\mathrm{Act}^{301}$ as well as some of the state food and drug legislation $^{302}$ are all implemented with the injunction remedy. The provisions in these statutes are much broader and more direct than that contained in the bill. In an excess of caution, the draftsmen have limited the section to repetitious violations and have assimilated it to the public nuisance cases. ${ }^{303}$ The legal necessity for the limitation is quite dubious, and it is highly questionable whether the constitutional difficulties are avoided by the qualifications. The obeisance to the assumed constitutional requirements may rob the remedy of effectiveness. One of the chief advantages of an injunction is its speed; to require proof of repetitious violations will often tend to defeat the purpose of the remedy. Moreover, it is not clear how many violations constitute a repetitious offense. Curiously, only the repetitious introduction of adulterated and misbranded articles may be restrained. As worded, it would seem that the government cannot proceed against the recipient, or in truth, anyone preparing or handling the illicit article save the shipper. Fortunately, the restraint upon false advertising is not so narrow. And the government is expressly spared the necessity of showing an intent to continue the statutory nuisance.

L. 580. For a federal statute providing for a maximum and minimum fine and imprisonment, see 14 StAт. 473 ( 1867 ), U. S. Rev. Stat. $\$ 3242$ (1878).

${ }_{20}$ See Sayre, Public Welfare Offenses (1933) 33 CoL. L. Rev. 55.

$\Rightarrow$ Id. at 57 et seq.

${ }_{278}^{26}$ STAT. 209 (1890), 15 U. S. C. A. $\$ 4$. See also the Clayton Act, 38 Srat. 736, I5 U. S. C. A. \$25; and the Wilson Tariff Act, 28 STAT. 570 (I894), I5 U. S. C. A. $\$ \$ 8,9$.

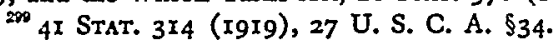

${ }^{200}$ Public No. 67,73 rd Cong. Ist sess. $\$ 3$ (c) (I933).

${ }^{202}$ Public No. 22, 73rd Cong. Ist sess. \$20, (1933).

${ }^{202}$ See N. J. Cosrp. StAT. (Supp. 1925) \$8I-156a (9); N. Y. LAws 1909, c. 9, art. 2, §II.

${ }^{303}$ State v. Ryder, I26 Minn. 95, I 47 N. W. 953 (I914); Popano Club v. State, 93 Fla. 4 I5, III So. 8or (1927); Fulton v. State, I7I Ala. 572, 54 So. 688 (I9II); see Carleton v. Rugg, I49 Mass. 550, 553, 22 N. E. 55, 56 (1889); of. Board of Medical Examiners v. Blair, 57 Utah 516, 196 Pac. 221 (I92I); (1933) 21 Kr. L. J. 178; (1933) 27 ILI. L. REv. 560. The nuisance doctrine has been used frequently to sustain health regulations. See Brown, Legislation for Health and Safety (I929) 42 HArv. L. Rev. 866, 873. 
The constitutional objections to the use of the injunction remedy are that it endows equity courts with criminal jurisdiction and deprives the alleged violator of the right to a jury trial. But the familiar maxim that equity will not enjoin criminal acts refers to instances where private individuals seek to stir the conscience of the equity court; it does not relate to injunctions sought by the state nor to the direct enlargement of equity jurisdiction by legislation. As for the invasion of the right to a jury trial, the constitutional guarantee applies only to criminal proceedings ${ }^{304}$ and a statute may therefore create a civil remedy of injunction which disregards the guarantee. ${ }^{305}$ The equitable proceeding is none the less civil and to be governed by equity procedure merely because the act to be enjoined may constitute a crime or because the complainant is the Government..$^{300}$

While the constitutional provision may thus be shown to be technically inapplicable, candor demands the admission that the governmental injunction affords an easy path for a subterranean encroachment upon the constitutional safeguard. The propriety of the use of the injunction in many instances is clear; in some cases the restraint will be oppressive. But to protect the stream of commerce against the introduction of illicit products or to protect it from obstructions and interference are well within the Congressional power. ${ }^{307}$ Whatever authority there is amply sustains the inclusion of the injunction sanction. ${ }^{308}$

The present Act contains no provision for the use of publicity as a sanction save that after judgment of a court in a food or drug matter, notice of the judgment may be published in such manner as may be prescribed by the Departmental rules and regulations. In accord therewith, through July, 1933, 20,I75 notices of judgments have been published. These notices are, however, legal summaries wholly inadequate to counteract the effects of false advertising and labeling. They go to a restricted audience and have proved ineffective. Without express statutory authority the Department has issued press releases. Possibly as a result of conservatism induced by the lack of such authority, these have been often too vague, general, and unpointed. The bill now places most extensive powers in the Secretary to publish the results of his findings and to disseminate such information regarding any food, drug, or cosmetic as he

\footnotetext{
ox Article 3, 52, cl. 3 of the Federal Constitution provides: "The trial of all crimes, except in cases of impeachment, shall be by jury, and such trial shall be held in the state where the said crimes shall have been committed. . . ."

${ }^{200}$ U. S. v. Trans-Missouri Freight Ass'n, I66 U. S. 290, I7 Sup. Ct. 540 (1897); In re Debs, 158 U. S. 564, 15 Sup. Ct. 900 (1895).

${ }^{200}$ See cases cited supra note 305, and U. S. v. Lockhart, 33 F. (2d) 597 (D. Neb. 1929).

${ }^{207}$ U. S. v. Trans-Missouri Freight Ass'n, supra note '305.

${ }^{306}$ There is not much authority on the question. The distinctions are still tenuous and inchoate. The Supreme Court had little diffculty with the Sherman Law. See note 305, stpra, and U. S. v. Elliott, 64 Fed. 27 (E. D. Mo. I894); cf. U. S. v. Agler, 62 Fed. 824 (D. Ind. I894); U. S. v. Railway Employees' Dept., 286 Fed. 228 (N. D. Ill. I923). The federal courts have disagreed as to the validity of Section 23 of the National Prohibition Act. This section permits an injunction against bootlegging, no matter where carried on. See, upholding the provision, U. S. v. Lockhart, supra note 306; Simon v. U. S., 62 F. (2d) 13 (C. C. A. 9th, 1932); cf. U. S. v. Rosoff, 27 F. (2d) 719 (C. C. A. 2d, 1928). But $c$. U. S. v. Cunningham, 2I F. (2d) 800 (D. Neb. I927), app. dis., 24 F. (2d) ro2I (C. C. A. 8th, 1928), s. c. 37 F. (2d) 349 (D. Neb. 1929) (declaring the section unconstitutional).
} 
deems necessary in the interest of public health and the protection of the consumer against fraud. ${ }^{309}$ The publicity powers of the Secretary are thus placed upon a par with those possessed by many state food commissioners. ${ }^{\mathbf{3 1 0}}$ Certainly, if wielded properly and aided by an alert and fearless press, the weapon of publicity can become the most trenchant. It is difficult to envisage just what restrictions may encumber the issuance of publicity, yet one doubts if the privilege on the part of the Secretary will be considered absolute by the courts. It is interesting to note a holding that a federal court cannot entertain a petition for mandamus to restrain the issuance of a food inspection decision despite a showing that the unfavorable publicity would injure a patentee. 311

In an effort to enlist the voluntary coöperation of the food, and drug industries the bill provides for a system of voluntary inspection. ${ }^{312}$ The gist of the plan is as follows: any manufacturer or packer of any food, drug, or cosmetic sold in interstate commerce may apply to the Secretary for the service. The Secretary is given discretion to designate supervisory inspectors to examine and inspect all the premises, equipment, methods, materials, containers and labels used by the applicant. If the article is found to conform to the requirements of the law, it may be so marked and such other facts relating to its identity or quality may be similarly noted in accord with departmental regulations. The services are to be rendered only after the applicant pays fees in such amount as to cover costs of the inspection and the reasonable costs of administration. In view of this last provision for payment, the system is hardly open to the charge of expending public sums for private enterprise. ${ }^{313}$ Yet the force of this sanction is not so innocently permissive and voluntary. By implication and the operation of the rule of expressio unius est alterius exclusio it denies to those who do not apply for the inspection the right to label and mark their products as products conforming to the federal law, a right now universally possessed by the packers and manufacturers subject only to the proviso that the claim be true. This denial raises a sharp question of discrimination and is not of too

$200 \mathrm{Brzr}, \$ 2 \mathrm{r}$.

${ }^{20}$ Cf. CAL. GeN. LAws (Deering, I93I) act. 57, \$r5; Irl. REv. Stat. (Cahill, 1929) c. 56b, \$I; Iowa Code (I93I) \$3050; N. D. CoMp. LAws ANN. (Supp. I926) \$2889aI3; N. Y. Cons. IAws (Cahill, 1930) c. I, 522; Miss. ANn. Code (Hemingway, 1930) \$4974; Ten. ANN. Code (Shannon, I932) \$6594; Hawail Rev. Laws (I925) \$I003; CAN. Rev. Stat. (I927) c. 76, 522.

" U. S. ex. rel. Alsop Process Co. v. Wilson, 33 App. D. C. 472 (1909). The publicity provisions of the 1924 Revenue Act were held constitutional in Hubbard $\nabla$. Mellon, 5 F. (2d) 764 (C. A. D. C. r925), on the ground that such publicity is appropriate as a means of enforcing a legitimate power. A federal court does not have jurisdiction in an action to prevent a journalistic crusade by a state food commissioner as it is not an action against a state within the meaning of the Eleventh Amendment. Scully v. Bird, 209 U. S. $48 \mathrm{r}, 28$ Sup. Ct. 597 (I908). "If this publication is made to those dealing in the article, it would be within the duty of the commissioner in advising of contemplated prosecution. If such publications are libelous, the law affords other means of redress." Arbuckle v. Blackburn, $x 1_{3}$ Fed. 616, 627 (C. C. A. 6th, I902), app. dismissed, rgr U. S. 405,24 S. Ct. 148 (I903). But state courts have enjoined publicity by food commissioners where the acts were deemed in excess of his authority. State ex. rel. Ladd v. District Court, 17 N. D. 285, II5 N. W. 675 (I908); Pratt Food Co. v. Bird, I48 Mich. 63I, I12 N. W. 701 (I907).

212 Bill, 522.

su See Note (1930) I8 CaIIF. I. REv. 697. 
sturdy validity. It should be noted also that the Secretary is under no duty to provide the service. Doubtless, his discretion must be exercised without arbitrary discrimination as between applicants, products, and classes of products.

Section 24 of the bill reads: "A right of action for damages shall accrue to any person for injury or death proximately caused by a violation of this Act." Section 24 is well-intentioned but may have most unexpected results. Does it add anything to the present state of the law? A violation today carries civil liability irrespective of privity in the case of misbranding and most types of adulteration. ${ }^{314}$ The express provision for a civil right of action may help in the case of injuries occasioned by the consumption of "naturally" adulterated products."315 Again, prima facie Section 24 gives a right of recovery where a consumer is injured by eating products shipped in interstate commerce by packers and manufacturers who fail to have licenses when required by the Secretary of Agriculture. Such a recovery for violation of license statutes has been denied on the ground that the violation does not proximately cause the injury. ${ }^{316}$ The continuance of the condition of proximate causation might seem to negate a civil recovery for violation of the license provision; but the character of the license required under the bill coupled with the language of Section 24 may extend the cause of action. ${ }^{317}$ The section does render obsolete any lingering question of privity of contract being needed for the recovery in tort.

But where the design of the legislative body has been to protect members of the public from particular types of injuries, the courts upon finding the design so limited have refused to permit the statutory violation to act as an avenue of recovery for the invasion of other interests. ${ }^{318}$ If this be true where the limitations on the design have

\footnotetext{
${ }^{314}$ See notes 280, 28I supra, for the effect of violation of the Act. In many of the cases dealing with suits in negligence for food poisoning, the disregard of relevant state statutes does not speak too highly for the lawyer's art. The weight of authority as to the effect of the violation of a state food and drug law in a civil suit is that the violation constitutes negligence per se. Greenwood v. Thompson Co., 213 Ill. App. 37 r (19x9); Portage Markets Co. v. George, xix Ohio 775, x46 N. E. 283 (1924); Fischer v. Golladay, 38 Mo. App. 53 I (I889); Hendry v. Judge \& Dolph Drug Co., 21 I Mo. App. 166, 245 S. W. 358 (r922); Kelley v. Daily Co., 56 Mont. 63, I8r Pac. 326 (rgrg); cf. Sutton's Adm'r v. Wood. r20 Ky. 23, 85 S. W. 201 (1905). See Note (1933) 33 Cor. L. Rev. 868, 87 I n. I6. But cf. Gearing v. Berkson, 223 Mass. 252, III N. E. 785 (I9r6); Culbertson v. Coca Cola Co., 157 S. C., 352, 154 S. E. 424 (1930); Tucker v. Graves, 17 Ala. App. 602, 88 So. 40 (1920); Travis v. Louisville \& N. R. Co., I83 Ala. 4I5, 62 So. 85 I (I9r3). The failure of the plaintiff to read or examine the label is not negligence as a matter of law. Hendry v. Judge \& Dolph Drug Co., supra. But the violation must be the proximate cause of the injury. People's Service Drug Stores v. Somerville, I6r Md. 662, I58 Atl. I2 (1932). The negligent omission of the retailer to inspect the food is not such intervening cause as to give immunity to the manufacturer. Maddox Coffee Co. v. Collins, I67 S. E. 306, 185 S. E. 470 (r932). In accord with the law generally, the mere fact that the article conforms to government standards or has passed governmental inspection does not remove the question of negligence. O'Connor v. Armour Packing Co., I58 Fed. 241 (C. C. A. 5th, I908); Kitterer v. Armour \& Co., 247 Fed. 921 (C. C. A. 2d, I917); Catani v. Swift \& Co., 25 I Pa. 52, 95 Atl. 93I (1915); Tiedje v. Haney, 184 Minn. 569, 239 N. W. 6rr (I93I). The allegation of a food and drug statute in a complaint may aid to convert a libel from one of goods to one of the person. Cf. Larsen v. Brooklyn Eagle, 165 App. Div. 4, 150 N. Y. Supp. 464 (2d Dept. x914). But cf. Hopkins Chemical Co. v. Read Drug, etc. Co., r24 Md. 2ro, 92 Atl. 478 (I9I4).

${ }^{315}$ See note 281 , supra. Cf. Mills Restaurant Co. v. Clark, I85 N. E. 470 (Oh. App. I933).

${ }^{310}$ See Note (1932) 32 Cor. L. Rev. 712, 718.

${ }^{\text {nx }}$ Cf. Goodwin v. Rowe, 67 Ore. I, 135 Pac. I7I (I913).

${ }^{213}$ See Note, supra note 316 , at 716 .
} 
not been expressed in the statute but have been judicially determined, a fortiori will it be true in an instance where the legislating body specifically adverts to the problem of civil recovery. When thus viewed, Section 24 is difficult to reconcile with the double aim of the statute: to guard the consumer from economic fraud as well as from bodily injury. Its effect would be to give violation of the Act non-conclusive force on the issue of negligence wherever the plaintiff seeks to recover for losses to his pocketbook. On the other hand, despite Section 24, the violation might still be deemed evidence of negligence in actions not covered by the expressly created statutory tort. ${ }^{318}$ The omission of a cause of action for economic loss seems unfortunate. Even more unfortunate would be the case if courts were to take the position that Congress in enacting Section 24 and adverting to a recovery in tort had by its silence completely legalized contracts for the shipment and sale of products in violation of the new law.

The statutory defense of guaranty is continued with several changes ${ }^{320}$ and extended to dealers who receive advertising copy but is expressly denied in all cases where the dealer's violation of the law is "wilful" and the dealer is prosecuted for such "wilful" offense. ${ }^{321}$ The bill also exempts publishers, advertising agencies, and radio broadcast licenses for the wilful or non-wilful dissemination of a false advertisement if on request they furnish the name and post-office address of the person who contracted for or caused them to disseminate the false advertisement. ${ }^{322}$

\section{Limitations of the Bill}

The scope of the bill has been indicated. Some of its limitations have been considered but others remain for discussion or re-emphasis. As far as misbranding and adulteration are concerned transportation continues to receive the classic exclusive

${ }^{210} \mathrm{Id}$.

${ }^{820}$ BrxL, $\$ 17$ (e). Section 9 of the Act provided that the guaranty must be to the effect that the article is not misbranded or adulterated within the meaning of the Act. Section 17 (e) of the bill requires merely a guaranty that the person signing it assumes full responsibility for any violation. Under the Act, the guaranty may be given by the person from whom the dealer purchases the article; under the bill it must be given by the person from whom he receives the article or the advertising copy thereof.

${ }_{321}$ Section 17 (e) of the bill is specifically limited to prosecutions under Section 17 (b) and apparently is not available for prosecutions under Section I7 (c). Several of the states seem to have gone even further than the bill and have denied the defense of the guaranty where the dealer knew or ought to have known that the article was adulterated or misbranded within the meaning of the Act. Since "wilfulness" is often difficult to prove, the provisions of these statutes as to guaranty seem preferable to that of the bill. Cf. Cal. Gen. Laws (Deering, 1931) act 57, \$22; Kan. Rev. Stat. AnN. (1923) \$65-609; Ill. Rev. Stat. (Cahill, 1929) c. $\$ 56 \mathrm{~b}, \$ 32$. Section 27 (d) provides that no guaranty operates as a defense if the dealer continues to sell the article after notice by the state food commissioner that the article is adulterated or misbranded or if the dealer fails to preserve for the guarantor and deliver to him upon demand the sample left with the dealer by the commissioner. In Canada and England, the analogous defense of warranty has been severely restricted. See I 8 \& 19 Geo. V, c. 3I, \$29; CaN. Rev. Stat. (I927) c. 76, \$24; Freeman, Labels as Warranties under the Adulteration Acts (1928) 92 Just. P. 808.

${ }^{322} \mathrm{BILL}, \xi_{17}$ (d). The section as worded requires a prior request which is discretionary. The wording is poor, and the Department has already announced that it will be changed so that the publisher violates the law only if, after request, he refuses. The Federal Trade Commission joins the publisher in false advertising cases. Cf. In re McGavan, II F. T. C. I25 (1927). Indicating the liability under the federal statute of a publisher of an obscene advertisement, see U. S. v. Kelly, Fed. Cas. No. 15514 (D. Nev. 1876) 3 Sawy. 566. 
emphasis. Misbranding and adulterating foods, drugs and cosmetics have not been made federal offenses and the result is not unlike waiting for an embezzeler to cross a state line before subjecting him to an arrest. The failure so to extend the law ${ }^{328}$ may work especial havoc to the bill's severe punishment of the wilful offender since the wilfulness must be shown in conjunction with the introduction into commerce of the misbranded or adulterated package, and the violator may often be the purchaser who transports the goods rather than the maleficent manufacturer. On the other hand, the interstate transportation of falsely advertised articles is not barred, and such articles may not be seized under the present provisions of the bill. Possibly the consumer will be protected from such articles in the case of most types of adulteration. However, where the danger lies in the use of the drugs as advertised, the bill's failure to arrest the passage of the articles to the consumer's medicine cabinet seems difficult of justification. The control of cosmetics is incomplete. As the bill is now phrased (unless in the rare instance where the cosmetic is also a "drug"), economic adulteration of cosmetics emerges scathless. ${ }^{824}$ There are no standards for quality or definition of identity authorized for cosmetics. ${ }^{325}$ Cosmetic containers may be deceptive as to shape or fill and one cosmetic may be offered under the name of another. ${ }^{826}$ Likewise the control of devices is far from complete. Under the bill's wording all types of receptacles for foods escape regulation. ${ }^{327}$

What is more serious is that the bill's excellent step in requiring affirmative preventive disclosure on the label is not paralleled by any like requirement as to advertising. ${ }^{328}$ Too often the hurried consumer under the impetus of advertising buys first and reads the latter later if at all. False advertising may continue to include false statements regarding a competitor's products.

The new sanctions could be stronger. No encouragement is given to coöperative enforcement on the part of private individuals or consumers' groups. ${ }^{820}$ In addition to the restriction on the injunction weapon which has been noted, there is no authority given to include in an injunction decree the requirement that the goods, labels and advertisements of violators be. inspected and certified by the department for a suitable period of time at the expense of the violator. A provision for costs in criminal prosecutions would tend to make the administration of the new law self-

sea That such a provisiofi would be constitutional is hardly open to doubt in view of U. S. v. Ferger, 250 U. S. 199, 39 Sup. Ct. 445 (1919), upholding a statute making it a crime to forge a bill of lading used in interstate commerce.

${ }^{224} \mathrm{Cf}$. BiLl, $\$ 5$.

205 Section II of the bill is confined to standards for foods.

$\$ C f$. Birl, $\$ 2$ (b), \$2 (c).

in But these are subjected to an indirect control by $\S_{3}$ (a) (4), $\S_{3}$ (a) (6) of the bill. The regulation of containers of foods is a reasonable exercise of the police power. People v. Frudenberg, 209 N. Y. 2I8, I03 N. E. I66 (1913) (milk container).

The only affirmative disclosure provision for advertising seems to be that if it includes the name of a disease for which a drug is not a specific cure but a palliative it must state that the drug is not a cure for such disease. Cf. Brit, $\$ 9$ (b).

200 Cf. N. D. Comp. LAws ANN. (Supp. I925) \$2889a6; VT. Gen. LAws (I917) \$6276. 
liquidating and if made mandatory, would offset the suspending of sentences. ${ }^{330}$ It would be particularly salutary if a violator of the false advertising provisions were forced as a penalty to publish at his own expense and in the same circulating media of his deception and with like blare the details of his conviction. Such a publicity weapon has been used abroad. ${ }^{331}$ The bill also makes advances in aid of the Secretary's investigation $\mathrm{s}^{322}$ but the absence of statutory provisions as to what should constitute prima facie evidence of violations ${ }^{333}$ is to be regretted. But even with its limitations, the bill, if enacted, would mark an epoch in the federal protection of the consumer.

26 Cf. N. D. Cospr. Laws ANs. (Supp. 2925) \$288gb23; OHto Gen. Code (Page, I93I) §12759; PA. Stat. (r920) \$71; Can. Rev. Stat. (I927) c. 76, \$34.

an Cf. German Food Law (Lebensmittelgesetz) (I9I7) \$16; French Trade-Mark Law (1857) art. r3;

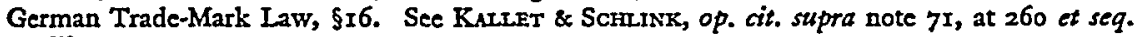

${ }^{20}$ BrLz, $\$ \$ 14,15$. Several of the states penalize interference with the government inspection. See note 23, supra.

${ }^{22 x}$ Many of the state food and drug laws provide that the certificate of the state analyst shall be prima facie evidence of tho facts therein stated. See, e. g., CAL. GeN. IAwS (Deering, I93I) act 57, SI4; FLA. GEN. LAWs (1927) \$3208; cf. CAN. REv. STAT. (1927) c. 76, \$13 (3); I8 \& 19 Geo. V, c. 31, \$28 (3). Some provide that possession of the adulterated article shall be prima facie evidence; others that the doing of the prohibited act raises a presumption of intent to violate. See, e. g., CAr. GEN. LAws (Deering, 193I) act 57, \$8; Irl. Rev. Stat. (Cahill, I929) c. 56b, \$4; Minn. Stat. (Mason, 1927) \$3807. 